\title{
Review \\ Development and Characterization of Bioadsorbents Derived from Different Agricultural Wastes for Water Reclamation: A Review
}

\author{
Julián Aguilar-Rosero ${ }^{1,+} \mathbb{D}$, María E. Urbina-López ${ }^{1,+}$, Blanca E. Rodríguez-González ${ }^{1,+}{ }^{\mathbb{D}}$, Sol X. León-Villegas ${ }^{1,+}$, \\ Itza E. Luna-Cruz ${ }^{2} \mathbb{D}$ and Diana L. Cárdenas-Chávez ${ }^{1, * \mathbb{D}}$
}

1 Tecnologico de Monterrey, School of Engineering and Science, Vía Atlixcáyotl 5718, Puebla 72453, Mexico; A00832705@itesm.mx (J.A.-R.); A01422987@itesm.mx (M.E.U.-L.); berodriguez@exatec.tec.mx (B.E.R.-G.); A01274156@itesm.mx (S.X.L.-V.)

2 Laboratory of Immunology and Virology, Biological Sciences Faculty, University Autonomus of Nuevo León, Avenida Pedro de Alba, San Nicolás de los Garza 66450, Mexico; itza.lunacrz@uanl.edu.mx

* Correspondence: diana.cardenas@tec.mx

+ These authors contributed equally to this work.

check for updates

Citation: Aguilar-Rosero, J.;

Urbina-López, M.E.;

Rodríguez-González, B.E.;

León-Villegas, S.X.; Luna-Cruz, I.E.;

Cárdenas-Chávez, D.L. Development

and Characterization of

Bioadsorbents Derived from

Different Agricultural Wastes for

Water Reclamation: A Review. Appl.

Sci. 2022, 12, 2740. https://doi.org/

10.3390/app12052740

Academic Editor: Carlos Rico de la

Hera

Received: 1 February 2022

Accepted: 24 February 2022

Published: 7 March 2022

Publisher's Note: MDPI stays neutral with regard to jurisdictional claims in published maps and institutional affiliations.

Copyright: (C) 2022 by the authors. Licensee MDPI, Basel, Switzerland. This article is an open access article distributed under the terms and conditions of the Creative Commons Attribution (CC BY) license (https:// creativecommons.org/licenses/by/ $4.0 /)$.

\begin{abstract}
The presence of dangerous pollutants in different water sources has restricted the availability of this natural resource. Thus, the development of new low-cost and environmentally-friendly technologies is currently required to ensure access to clean water. Various approaches to the recovery of contaminated water have been considered, including the generation of biomaterials with adsorption capacity for dangerous compounds. Research on bioadsorbents has boomed in recent years, as they constitute one of the most sustainable options for water treatment thanks to their abundance and high cellulose content. Thanks to the vast amount of information published to date, the present review addresses the current status of different biosorbents and the principal processes and characterization methods involved, focusing on base biomaterials such as fruits and vegetables, grains and seeds, and herbage and forage. In comparison to other reviews, this work reports more than 60 adsorbents obtained from agricultural wastes. The removal efficiencies and/or maximum adsorption capacities for heavy metals, industrial contaminants, nutrients and pharmaceuticals are presented as well. In addition to the valuable information provided in the literature investigation, challenges and perspectives concerning the implementation of bioadsorbents are discussed in order to comprehensively guide selection of the most suitable biomaterials according to the target contaminant and the available biowastes.
\end{abstract}

Keywords: biowastes; bioadsorbents; activated carbon; raw wastes; heavy metals; industrial contaminants; nutrients; pharmaceuticals

\section{Introduction}

Water pollution has increased in recent decades as a consequence of the uncontrolled disposal of agricultural and industrial residues and domestic discharge directly into water bodies and soil, which can then reach underground sources via filtration. Two of the most common contaminants are textile dyes and heavy metals; approximately $20 \%$ of industrially-employed dyes are discharged in effluents, while heavy metals are often the result of waste from hospitals and factories. Both types of pollutants are considered important hazards for human and environmental health even at trace levels. These non-biodegradable pollutants are found in surface and ground water sources and accumulated in aquatic organisms, primarily because conventional wastewater treatments cannot completely remove them from the effluent [1-5]. There are other water contaminants, such as organic matter, pharmaceuticals, pesticides, fertilizers, chemicals from personal care products, and many micro-organic pollutants; these are known as emerging contaminants. They are characterized by the majority being unregulated substances generated from anthropogenic activities, 
and can only be detected by chromatography methods coupled to mass spectrometry. Even though they are present in the environment at very low concentrations (nanograms or pictograms), their adverse effects are significant. The consequences of these pollutants are diverse, generating long-term effects on aquatic life and human health such as endocrine disruption, carcinogenesis, mutagenesis, and reproductive and embryonic toxicity, among others [6-8]. Reports from the United Nations Educational, Scientific and Cultural Organization state that every day over two million tons of sewage and other effluents drain into water bodies, forcing one out of nine people in the world to consume water from unsafe sources [9]. Therefore, the necessity of environmentally friendly and affordable treatments is a priority.

Different technologies have been developed to treat wastewater before it enters rivers, oceans, or other water sources, including chemical, physical, and biological methods. Their application depends on punctual permissible levels of the effluent, the cost of the process, and environmental compatibility. These techniques include sedimentation, filtration, ion exchange, flotation, electrolysis, microbial reduction, bioremediation, and adsorption [10-12]. Biosorption is described as the process that occurs when the adsorbate or pollutant is retained on the surface of the adsorbent (biomaterial), creating a molecular or atomic film owing to residual interactions such as Van Der Waals forces or covalent bonds [13-15]. When biosorption is applied on wastewater treatment, it involves the interaction of the liquid phase component with the surface of the solid by either a chemical (chemisorption) or physical (physisorption) process, generating a mono- or multilayer (Figure 1). Similar to synthetic resins, heavy metals or other charged contaminants bind to the adsorbent biomaterial through electrostatic interactions and ion exchange.

A

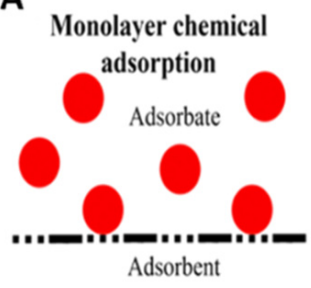

B

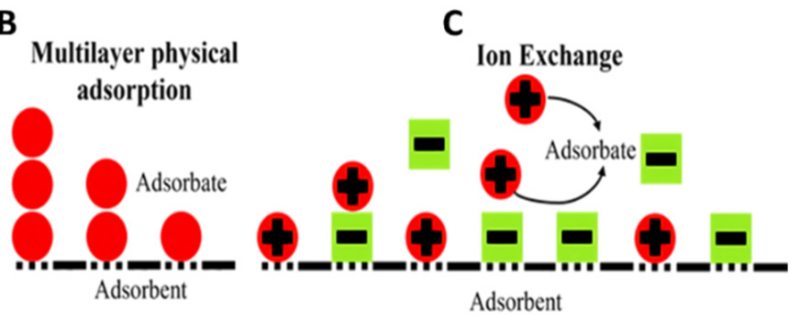

Figure 1. Adsorption mechanisms: (A) chemisorption monolayer; (B) physisorption multilayer; and (C) ion exchange adsorption.

Agricultural residues have been proposed as low-cost unconventional adsorbents due to their high content of cellulose and lignocellulose [1]. Grains, seeds, fruits, vegetables, herbage, and forage, which represent the most abundant wastes in food and agricultural industries, have great potential as adsorbent materials capable of remediating polluted effluents [3]. However, several conditions must be considered for the optimal removal of contaminants in addition to the production volume, such as the chemical and physical characteristics of the bioresidues and their operation parameters $(\mathrm{pH}$, contact time, adsorbent dose, particle size, contaminant concentration, temperature, adsorption kinetics, and isothermal behavior). $\mathrm{pH}$ is one of the most important parameters, as it can improve or weaken removal efficiency by affecting the solubility of metal ions as well as the physical properties, structure, and availability of active sites on the surface of the adsorbent $[11,15,16]$. A high adsorbent dosage provides a higher number of active sites, and consequently increases the adsorption capacity until equilibrium is reached at which an excess adsorbent does not further improve removal efficiency [15]. The adsorption capacity can be further increased by reducing the particle size of the adsorbent, as there is then a higher surface area and the limitations caused by mass and diffusional transfer are decreased. This allows molecules to reach sorption sites more easily, and the capture of the adsorbate occurs in a shorter time $[15,17,18]$. Furthermore, the adsorption capacity increases as the contaminant concentration rises, which is calculated by isothermal models that estimate the maximum sorption capacity of the adsorbent $\left(\mathrm{q}_{\mathrm{m}}\right)$ at a given temperature 
given the possible adsorption mechanisms [17,19]. Langmuir and Freundlich isotherms are two of the most common models employed to describe different bioadsorbents. However, the Dubinin-Radushkevic, Temkin, and other models have been used in specific cases, e.g., where the carbonaceous material capacity is defined by neither layer-by-layer adsorption nor a constant adsorption potential, or when the adsorption behavior is characterized by uniform energy distribution [20-22]. The adsorption kinetics indicate the influence of the contact time, which depends on the adsorbate concentration, temperature, and adsorbent characteristics (surface and pore size). There are several kinetic models; however, two that are generally applied in bioadsorbent studies are the pseudo-first and pseudo-second order models [23]. Both models deduce the sorption occurring on localized sites without interaction among the adsorbed ions until it reaches a maximum point on the saturated monolayer [24]. In the context of the current relevance and application of bioadsorbents for water bioremediation, although many authors have reported on several options for the removal of a wide range of contaminants, at present this information is distributed across many studies focused on a single type of contaminant or bioresidue. The present paper seeks to organize this vast amount of information into three major categories of low-cost agricultural adsorbents, namely, grains and seeds, fruits and vegetables, and herbage and forage waste, for the removal of the main groups of pollutants (heavy metals, industrial chemicals, nutrients, and pharmaceuticals) found in different water sources. Bioadsorbents derived from these three categories are described and compared here along with information on both adsorbents and the key parameters that influence the adsorption process. We sought to compile the largest collection of information on bioadsorbents reported to date in a single bibliographical source in order to allow future researchers to easily determine the most suitable alternative in each case.

\section{Methods}

The methodological approach followed to this literature review is briefly described below. The main topics were waste-based adsorbents and water remediation. These residues were categorized into three main groups: fruits and vegetables, grains and seeds, and herbage and forage. The search based on the Science Direct database was carried out from May to August 2021 using the keywords "seeds", "fruit", "vegetable", "forage", "herbage", "silage", "cereal" "water treatment", "grain", "beans contaminant", "wastewater", "by-product", "adsorption", "micronutrients" and different combinations of the same. Commands such as "AND" and "OR" were included in order to improve the investigation. Approximately 120 publications (scientific articles and reviews) from the last ten years were screened and examined. The selection parameters included relevant information about removal efficiency, adsorption and kinetic models, waste sources, and removal of specific groups of contaminants (pharmaceuticals, dyes, heavy metals, and nutrients). Book chapters and reports of international organizations were included as references for specific topics and concepts. It is important to explain that the inclusion of the herbage and forage category resulted from a meticulous search for residues derived from leaves and stems such as sugarcane bagasse (SCB), tea, date palm tree leaves and fibers, sunflower stalks and leaves, cauliflower leaf powder, potato stem and leaf powder, grape stalks, corn stalks, and straw of cereals such as rice, wheat, barley, and soybeans. The corn cob was considered a vegetable due to its peculiar way of sprouting from the stalk plant.

\section{Obtaining Waste-Based Bioadsorbents}

The use of grains and seeds for water treatment can be classified into three categories: flocculation-coagulation processes [25,26]; generation of activated carbon (AC) [27]; and production of bioadsorbent materials [28]. Hibiscus seeds have been used as a worthy example for the removal of organic matter from water. It is first necessary to dry and grind the seeds before resuspending the product in $\mathrm{NaCl}$ solution; it must then be defatted with hexane to obtain extracts and proteins with coagulant activity [25]. Other seeds have been tested, such as Moringa oleifera, common beans, and mustard seeds [29,30]. Several 
examples from the other two categories are described below, highlighting the type of physical or chemical pre-treatment employed in their use as bioadsorbents.

\subsection{Activated Carbon Production}

The synthesis of AC from low-cost waste materials and its subsequent use as a biosorbent has become more common. Generally, AC implementation requires pre-treatment before application to contaminated waters; the use of microwaves [31], ultrasound techniques [32], or chemical agents for biochar activation have all shown promising results. Furthermore, the use of different chlorides such as $\mathrm{NaCl}, \mathrm{KCl}$, and $\mathrm{CaCl}_{2}$ has resulted in $\mathrm{AC}$ with better adsorption capacity $[25,33]$. The common way to activate biowaste-based carbon is after carbonization, although in certain cases the activation is carried out before. This can be physical (e.g., pressurization, pyrolysis, or gasification) and / or chemical (e.g., by using acid, alkali, or salt compounds) depending on the nature of the waste and its further application [34-36].

The removal of heavy metals with AC using seed and grain wastes has been widely explored, as in the case of the buttons (female flowers) that are one of the most abundant residues in coconut plantations (comprising about $55-95 \%$ of remains). This coconut waste was evaluated by Anirundhan and Sreekumari [37] for the adsorption of different heavy metals from industrial effluents. The buttons were treated with sulfuric acid and placed inside a graphite tube in a furnace to generate $\mathrm{AC}$; the collected carbonized material showed high metal removal performance (100\%). Spent coffee waste is another material commonly used to adsorb a wide range of contaminants present in fresh water and wastewater through carbon activation by $\mathrm{NaOH}$ [38]. AC from fruit waste such as papaya peel can be an effective adsorbent to remove lead from contaminated water. This biowaste was dried $\left(105^{\circ} \mathrm{C}\right)$ and carbonized, followed by a chemical activation process using $\mathrm{H}_{3} \mathrm{PO}_{4}$ as the oxidant agent [39]. Concerning AC derived from forage and herbage sources (e.g., cereal byproducts and palm tree leaves), these must first pass through a drying process, then be soaked in acid solution, and finally carbonized into a particle size between 300-425 $\mu \mathrm{m}$. This has the aim of adjusting the kinetic model at $56^{\circ} \mathrm{C}$ in order to effectuate the capacity to remove heavy metals such as $\mathrm{Pb}(\mathrm{II})$ and $\mathrm{Cr}(\mathrm{VI})$ from aqueous solutions [40,41].

The AC sources employed to remove dyes and other industrial pollutants comprise a long list of several types of vegetable wastes. Peanut shells have been transformed into AC through chemical treatment with $\mathrm{H}_{3} \mathrm{PO}_{4}$ and used to adsorb acid yellow 36 [42]. The same chemical modification was performed with Acacia erioloba seed biochar to increase its surface area and porosity and thereby improve the adsorption yield for methylene blue (MB) and iodine [43]. Other authors processed coffee waste with $\mathrm{KOH}$ and pyrolysis to obtain granular $\mathrm{AC}$ into calcium alginate beads for the treatment of dye contaminants, finding that the material could be used for up to seven cycles [44]. The efficiency of $\mathrm{H}_{3} \mathrm{PO}_{4}$ as a carbon activator was compared with that of $\mathrm{ZnCl}_{2}$ in the context of siriguela seeds and cocoa shells for the adsorption of bovine serum albumin (BSA) and $\alpha$-lactalbumin $\left(\alpha\right.$-Lac), which are food industry wastes; $\mathrm{H}_{3} \mathrm{PO}_{4}$ was more effective for $\alpha$-Lac, while $\mathrm{ZnCl}_{2}$ performed better in BSA removal [45]. Coir pith subjected to a carbonization treatment at $700{ }^{\circ} \mathrm{C}$ was used in a single and a multi-component system to adsorb congo red, rhodamine$\mathrm{B}$, and acid violet $[46,47]$. Another fruit-based biochar that has been widely studied is that resulting from pineapple waste (crowns, leaves and stems). These residues were subjected to pyrolysis and permeated with $\mathrm{ZnCl}_{2}$ to turn them into AC with a prominent adsorption capacity for dyes (e.g., MB) thanks to a large surface area $\left(914.67 \mathrm{~m}^{2} / \mathrm{g}\right)$ [48].

A wide variety of other agricultural wastes have been tested to produce $\mathrm{AC}$ for the removal of nutrients and pharmaceuticals such as sodium diclofenac, diclofenac, carbamazepine, sulfamethoxazole, and ibuprofen, among others. As an example, rice husk and lemon juice residue (solid after juice extraction) were explored as adsorbents for phosphate sequestering. The dried residues were submerged in $\mathrm{NaOH}$ followed by $\mathrm{H}_{2} \mathrm{SO}_{4}$ for their respective activation; both were then dried, carbonized, and finally sieved to a 250-350 $\mu \mathrm{m}$ particle size [49]. Likewise, rubber pod husk showed favorable results for 
removing phosphates through chemisorption and a multilayer process after undergoing chemical treatment with $\mathrm{H}_{3} \mathrm{PO}_{4}$ to activate its adsorbent capacity [50]. A low percentage of cacao pod husk generated during chocolate production is recycled as a fertilizer and the rest is discarded. This massive generation facilitates its transformation into AC when treated with $\mathrm{H}_{2} \mathrm{SO}_{4}$ for the removal of sodium diclofenac from aqueous solutions [51]. Chemical activation with $\mathrm{H}_{3} \mathrm{PO}_{4}$ was further implemented by El Mouchtari et al. [52] on a carbon composite based on Argania spinosa tree nutshells and $\mathrm{TiO}_{2}$. The latter modified the properties of the adsorbent by increasing the surface area and easily retaining diclofenac, carbamazepine, and sulfamethoxazole as well as the photolysis of the pharmaceuticals. Chakraborty et al. [53] and Cabrita et al. [54] used ACs from Aegle marmelos (wood apple) shells and peach stones with physical and chemical activation, respectively, to remove ibuprofen and acetaminophen from water sources. The pretreatment conditions, including the carbonization and pyrolysis temperatures employed to obtain the different activated carbons from biowastes, are summarized in Table 1.

Table 1. Generation and characterization of activated carbon derived from agricultural residues (grains, seeds, fruits, vegetables, herbage, and forage) to remove heavy metals, industrial contaminants, ions, and pharmaceuticals.

\begin{tabular}{|c|c|c|c|c|}
\hline Biowaste & Pretreatment & Characterization & Contaminant & Ref. \\
\hline Acacia erioloba seed & $\begin{array}{c}\text { Chemical activation }\left(\mathrm{H}_{2} \mathrm{SO}_{4}\right) \\
\text { Pyrolysis }\left(600^{\circ} \mathrm{C}\right)\end{array}$ & $\begin{array}{l}\text { SEM, XRD, BET, } \\
\text { FTIR, EDX }\end{array}$ & $\mathrm{MB}$, iodine & [43] \\
\hline Aegle marmelos shell & $\begin{array}{c}\text { Carbonization }\left(650^{\circ} \mathrm{C}\right) \text {, Steam } \\
\text { activation }\left(800^{\circ} \mathrm{C}\right)\end{array}$ & SEM, BET, FTIR, PZC & IBU & [53] \\
\hline $\begin{array}{l}\text { Argania spinosa tree } \\
\text { nutshells }\end{array}$ & $\begin{array}{l}\text { Chemical activation }\left(\mathrm{H}_{3} \mathrm{PO}_{4}\right) \\
\text { Carbonization }\left(500{ }^{\circ} \mathrm{C}\right)-\mathrm{TiO}_{2} \\
\text { Impregnation }\end{array}$ & $\begin{array}{l}\text { FTIR, SEM-EDS, TGA, } \\
\text { XRD, BET }\end{array}$ & CBZ, SMX, DCF & [52] \\
\hline Cacao pod husk & $\begin{array}{l}\text { Chemical activation }\left(\mathrm{H}_{2} \mathrm{SO}_{4}\right) \\
\text { Carbonization }\left(600^{\circ} \mathrm{C}\right)\end{array}$ & SEM, FTIR, EDX & SD & [51] \\
\hline $\begin{array}{l}\text { Cacao shells and } \\
\text { Siriguela seeds }\end{array}$ & $\begin{array}{l}\text { Chemical activation }\left(\mathrm{ZnCl}_{2}, \mathrm{H}_{3} \mathrm{PO}_{4}\right), \\
\text { Carbonization }\left(500^{\circ} \mathrm{C}, \mathrm{N}_{2}\right)\end{array}$ & $\begin{array}{l}\text { FTIR, DTA/TG, } \\
\text { BET, BJH }\end{array}$ & $\alpha$-Lac I, BSA & [45] \\
\hline Cereal byproducts & Carbonization $\left(600^{\circ} \mathrm{C}\right)$ & N.R & $\mathrm{Cr}(\mathrm{VI})$ & [40] \\
\hline Coconut buttons & $\begin{array}{l}\text { Chemical activation }\left(\mathrm{H}_{2} \mathrm{SO}_{4}\right) \text {, Steam } \\
\text { carbonization }\left(400{ }^{\circ} \mathrm{C}\right)\end{array}$ & $\begin{array}{l}\text { FTIR, XRD, SEM, TGA, } \\
\text { PZC, BET }\end{array}$ & $\mathrm{Pb}(\mathrm{II}), \mathrm{Hg}(\mathrm{II}), \mathrm{Cu}(\mathrm{II})$ & [37] \\
\hline Coir pith & Carbonization $\left(700^{\circ} \mathrm{C}\right)$ & N.R & $\mathrm{CR}, \mathrm{RB}, \mathrm{AV}$ & {$[46,47]$} \\
\hline Palm tree leaves & $\begin{array}{l}\text { Chemical activation }\left(\mathrm{H}_{2} \mathrm{SO}_{4}\right) \\
\text { Carbonization }\left(250-450{ }^{\circ} \mathrm{C}\right)\end{array}$ & FTIR, SEM-EDX, BET & $\mathrm{Pb}(\mathrm{II})$ & {$[41]$} \\
\hline Papaya Peel & $\begin{array}{c}\text { Carbonization }\left(450^{\circ} \mathrm{C}\right) \\
\mathrm{H}_{3} \mathrm{PO}_{4} \text { Oxidation }\end{array}$ & $\begin{array}{l}\text { FESEM, SEM-EDX, } \\
\text { FTIR, BET, XRD }\end{array}$ & $\mathrm{Pb}(\mathrm{II})$ & [39] \\
\hline Peach stones & $\begin{array}{l}\text { Chemical activation }\left(\mathrm{K}_{2} \mathrm{CO}_{3}\right), \\
\text { Carbonization }\left(700{ }^{\circ} \mathrm{C}\right)\end{array}$ & $\begin{array}{l}\mathrm{N}_{2} \text { and } \mathrm{CO}_{2} \\
\text { adsorption, } \mathrm{PZC} \text {, } \\
\text { thermal analysis }\end{array}$ & $\mathrm{ACP}$ & [54] \\
\hline Peanut Shell & $\begin{array}{c}\text { Chemical activation }\left(\mathrm{H}_{3} \mathrm{PO}_{4}\right), \\
\text { Pyrolysis }\left(650^{\circ} \mathrm{C}, \mathrm{N}_{2}\right)\end{array}$ & $\begin{array}{l}\text { TGA, FESEM, EDS, } \\
\text { BET, FTIR }\end{array}$ & AY-36 & [42] \\
\hline Pineapple waste & $\begin{array}{c}\text { Chemical activation }\left(\mathrm{ZnCl}_{2}\right) \\
\text { Pyrolysis }\left(500^{\circ} \mathrm{C}\right)\end{array}$ & BET, BJH, FTIR, SEM & MB & [48] \\
\hline $\begin{array}{l}\text { Rice husk and Lemon } \\
\text { juice residue }\end{array}$ & $\begin{array}{c}\text { Chemical activation }\left(\mathrm{NaOH}, \mathrm{H}_{2} \mathrm{SO}_{4}\right), \\
\text { Carbonization }\left(650^{\circ} \mathrm{C}\right)\end{array}$ & FTIR, BET, BJH & Phosphates & [49] \\
\hline Rubber pod husk & $\begin{array}{c}\text { Chemical activation }\left(\mathrm{H}_{3} \mathrm{PO}_{4}\right) \\
\text { Pyrolysis }\left(500^{\circ} \mathrm{C}\right)\end{array}$ & $\begin{array}{l}\text { BET, SEM, EDX, } \\
\text { FTIR, PZC }\end{array}$ & Phosphates & [50] \\
\hline Spent Coffee & $\begin{array}{c}\text { Chemical activation }(\mathrm{NaOH}) \\
\text { Pyrolysis }\left(800^{\circ} \mathrm{C}\right)\end{array}$ & UHR-SEM, FTIR & NPX, DCF, IBU & [38] \\
\hline Spent Coffee (Granular) & $\begin{array}{l}\text { Chemical activation }(\mathrm{KOH}) \text {, Pyrolysis } \\
\left(700^{\circ} \mathrm{C}\right) \text {, Granulation }\end{array}$ & $\begin{array}{l}\text { SEM, FTIR, BET, BJH, } \\
\text { Horvath-Kawazoe }\end{array}$ & $\mathrm{AO} 7, \mathrm{MB}$ & {$[44]$} \\
\hline
\end{tabular}

N.R, not reported; MB, Methylene blue; IBU, Ibuprofen; CBZ, Carbamazepine; SMX, Sulfamethoxazole; DCF, Diclofenac; SD, Sodium diclofenac; CR, Congo red; RB, Rhodamine B; AV, Acid violet; ACP; Acetaminophen; AY-36, Acid yellow 36; NPX, Naproxen; AO7, Acid orange 7; EDS, Energy Dispersive Spectrometer; UHR-SEM, Ultra-High Resolution Scanning Electron Microscope. 


\subsection{Raw Wastes as Bioadsorbents}

Many of the biosorbents that have been studied for the removal of pollutants were employed in raw form with or without chemical, physical, or even magnetic pretreatment (Table 2). Residues such as exhausted coffee can be used without any chemical modification to adsorb hazardous contaminants such as $\mathrm{Hg}$ (II) found in industrial effluents [55]. Raw tamarind seeds have been presented as a remarkable alternative for the removal of $\mathrm{Pb}(\mathrm{II})$ ions because of their high content of lignocellulose along with surface groups such as phosphorus, magnesium, vitamin $\mathrm{C}$, potassium, calcium, and proteins, which can be chemically modified by $\mathrm{H}_{2} \mathrm{SO}_{4}$ (1:2 weight ratio) and ultrasonic waves $(24 \mathrm{kHz})$ to increase their surface area [32]. Araújo et al. [56] and Çelekli et al. [57] used Moringa oleifera seed powder (75-500 $\mu \mathrm{m}$ particle size) without pretreatment to adsorb silver and reactive red 120 dye. Because the presence of surface functional groups is crucial to synthesize materials with higher adsorption capacity, Edathil et al. [28] developed a magnetic spent coffee nanocomposite with $\mathrm{Fe}_{3} \mathrm{O}_{4}$ nanoparticles to increase its affinity to $\mathrm{Pb}$. Coconut is one of the most abundant agro-industrial products, and is able to remove several heavy metals by taking advantage of the fact that approximately $62-65 \%$ of the whole fruit (coir pith, coconut bunch, and husk) is considered waste [10,58]. For instance, coir pit was employed without chemical pre-treatment for the removal of $\mathrm{Co}(\mathrm{II}), \mathrm{Cr}(\mathrm{III})$ and $\mathrm{Ni}(\mathrm{II})$ after being air-dried, ground, and sieved using a 300-600 $\mu \mathrm{m}$ mesh [59]. Banana peels were used by Memon et al. $[60,61]$ for $\mathrm{Cd}(\mathrm{II})$ and $\mathrm{Cr}(\mathrm{VI})$ adsorption. Dried slices of banana peel were crushed and passed through a mesh of $125 \mu \mathrm{m}$, re-dried in an air oven at $100{ }^{\circ} \mathrm{C}$, and finally esterified with acidic methanol. Watermelon rinds have characteristics suitable for the removal of metal elements $(\mathrm{Zn}, \mathrm{Pb}$ and $\mathrm{Cr}$ ) in their native form and after employing calcium hydroxide and citric acid treatment $(\mathrm{Cu})$, followed by a drying and crushing process a particle diameter between 150 and $300 \mu \mathrm{m}$ can be achieved [62-66]. Certain functional groups such as carboxyl and hydroxyl are responsible for the sorption of pollutants [3].

Table 2. Pretreated and non-treated raw biowastes implemented as bioadsorbents to remove a wide variety of heavy metals, industrial contaminants, ions, and pharmaceuticals.

\begin{tabular}{|c|c|c|c|c|}
\hline Biowaste & Pretreatment & Characterization & Contaminant & Ref. \\
\hline Banana peel & $\begin{array}{c}\text { No treatment, Esterification } \\
(\mathrm{MeOH}-\mathrm{HCl})\end{array}$ & FTIR, BET, SEM, PZC, EDX & $\begin{array}{l}\text { MO, MB, RB, CR, MV, } \\
\text { AB-10, F, Cd(II), Cr(VI) }\end{array}$ & {$[60,61,67,68]$} \\
\hline Barley straw & $\begin{array}{l}\text { No treatment, Citric } \\
\text { acid-NaOH treatment, } \\
\text { Magnetic modification }\end{array}$ & FTIR, SEM & $\mathrm{BBY}, \mathrm{CV}, \mathrm{MB}, \mathrm{SO}$ & [69] \\
\hline Cauliflower leaf & No pretreatment & FTIR, SEM & MB & [70] \\
\hline Coffee husk & No pretreatment & BET, FTIR, PZC, SEM-EDS & NFX & [71] \\
\hline Coconut coir dust & No pretreatment & FTIR & MB & [72] \\
\hline Coir pith & No pretreatment & N.R & $\mathrm{Co}(\mathrm{II}), \mathrm{Cr}(\mathrm{III}), \mathrm{Ni}(\mathrm{II})$ & [59] \\
\hline Corn cob and stalk & $\begin{array}{l}\text { No treatment, Formaldehyde, } \\
\text { NaOH-H } \mathrm{SO}_{4} \text { treatment }\end{array}$ & N.R & $\mathrm{Cu}, \mathrm{Ni}, \mathrm{Cd}, \mathrm{Pb}$ & [73] \\
\hline Durian peels & $\mathrm{HCl}$ treatment & N.R & AG25 & [74] \\
\hline Grapefruit peel & No pretreatment & FTIR & $\mathrm{CV}$ & [75] \\
\hline Jackfruit peel & No pretreatment & N.R & MB & [76] \\
\hline Kiwi and Tangerine peels & $\mathrm{NaOH}$ treatment & N.R & $\mathrm{Cd}(\mathrm{II}), \mathrm{Cr}(\mathrm{III}), \mathrm{Zn}(\mathrm{II})$ & [77] \\
\hline Mango peel & No pretreatment & PZC, FTIR, SEM, EDX & $\mathrm{Cd}(\mathrm{II}), \mathrm{Pb}(\mathrm{II})$ & [78] \\
\hline Mangosteen pericarps & No Pretreatment & SEM, FTIR, EDX, XPS, XAS & $\mathrm{I}^{-}$ & [79] \\
\hline Moringa oleifera seeds & No pretreatment & FTIR, SEM & RR-120, Ag(I) & {$[56,57]$} \\
\hline Orange peel & No pretreatment & BET, SEM & $\begin{array}{l}\text { CR, PO, RB, MO, MB, MV, } \\
\text { AB-10, DR23, DR80 }\end{array}$ & {$[67,80,81]$} \\
\hline Passion fruit rinds & No Pretreatment & SEM, FTIR, EDX, XPS, XAS & $\mathrm{I}^{-}$ & [79] \\
\hline Peanut husk & $\begin{array}{l}\text { Chemical modification } \\
\left(\mathrm{Fe}_{3} \mathrm{O}_{4}-\mathrm{IA}-\mathrm{Zr}\right)\end{array}$ & BET, SEM, FTIR, XPS, VSM, XRD & Phosphates & [82] \\
\hline Pomelo peel & No pretreatment & ZP, FESEM, FTIR, BET & RB-114 & [83] \\
\hline
\end{tabular}


Table 2. Cont.

\begin{tabular}{|c|c|c|c|c|}
\hline Biowaste & Pretreatment & Characterization & Contaminant & Ref. \\
\hline Potato leaf/stem & No pretreatment & FTIR, SEM & $\mathrm{MB}, \mathrm{MG}$ & [84] \\
\hline $\begin{array}{l}\text { Red onion and Red } \\
\text { dragon fruit peels }\end{array}$ & No Pretreatment & SEM, FTIR, EDX, XPS, XAS & $\mathrm{I}^{-}$ & [79] \\
\hline Rice husk & No Pretreatment & BET, FTIR, PZC, SEM-EDS & NFX & [71] \\
\hline Rice straw & No Pretreatment & FTIR, BET, FTIR, SEM, EDX & CFA, CBZ, Pb(II) & {$[16,85]$} \\
\hline Soybean and wheat straw & $\begin{array}{l}\text { No treatment, Formaldehyde, } \\
\mathrm{NaOH} \text { and } \mathrm{H}_{2} \mathrm{SO}_{4} \text { treatment. }\end{array}$ & N.R & $\mathrm{Cu}, \mathrm{Ni}, \mathrm{Cd}, \mathrm{Pb}$ & [73] \\
\hline Spent ground coffee & $\begin{array}{l}\text { No treatment, Magnetic } \\
\text { modification }\left(\mathrm{Fe}_{3} \mathrm{O}_{4} \text { NPs }\right)\end{array}$ & BET, XRD, FTIR, SEM-EDX, ZP & $\mathrm{Hg}(\mathrm{II}), \mathrm{Pb}(\mathrm{II})$ & {$[28,55]$} \\
\hline Sugarcane bagasse (SCB) & $\begin{array}{c}\text { No treatment, } \mathrm{NaOH}, \\
\text { HCl treatments }\end{array}$ & FTIR, SEM & $\begin{array}{l}\mathrm{Fe}(\mathrm{III}), \mathrm{Cu}(\mathrm{II}), \mathrm{Pb}(\mathrm{II}), \mathrm{Zn}(\mathrm{II}) \\
\mathrm{Cd}(\mathrm{II}), \mathrm{Co}(\mathrm{II}), \mathrm{Mn}(\mathrm{II})\end{array}$ & {$[86,87]$} \\
\hline SCB and beet pulp & $\mathrm{NaOH}$ treatment & FTIR, SEM & $\mathrm{Mn}(\mathrm{II})$ & [88] \\
\hline Sunflower leaf/stalk & $\begin{array}{l}\text { No treatment, } \mathrm{NaOH} \\
\text { activation (Ni removal) }\end{array}$ & PZC, SEM & $\mathrm{Fe}, \mathrm{Mn}, \mathrm{Zn}, \mathrm{Ni}, \mathrm{Cu}, \mathrm{Cd}$ & [89] \\
\hline Tamarind seeds & $\begin{array}{c}\mathrm{H}_{2} \mathrm{SO}_{4} \text { treatment., } \\
\text { Ultrasonic modification }\end{array}$ & FTIR, SEM & $\mathrm{Pb}(\mathrm{II})$ & {$[32]$} \\
\hline Tea waste (Black tea) & $\begin{array}{c}\text { No treatment, } \\
\text { Sulfonation }\left(\mathrm{H}_{2} \mathrm{SO}_{4}\right)\end{array}$ & $\begin{array}{l}\text { BET, BSLLD, SEM-EDX, FTIR, } \\
\text { TGA, Raman, XPS, ESR, SAXS }\end{array}$ & $\mathrm{Cu}, \mathrm{Pb}, \mathrm{MB}$, Tet, $\mathrm{Cr}(\mathrm{VI})$ & {$[90,91]$} \\
\hline Tea waste (mixed tea) & No pretreatment & SEM, TEM, EDS, BET, FTIR, XPS & $\mathrm{Mn}(\mathrm{II}), \mathrm{Zn}(\mathrm{II}), \mathrm{Cr}(\mathrm{VI})$ & {$[92,93]$} \\
\hline Watermelon rinds & $\begin{array}{c}\text { No treatment, } \mathrm{Ca}(\mathrm{OH})_{2} \text {, Citric } \\
\text { acid treatments }\end{array}$ & SEM-EDX, BET, MP, PZC, FTIR & $\mathrm{Zn}, \mathrm{Pb}, \mathrm{Cu}(\mathrm{II}), \mathrm{Cr}(\mathrm{III})$ & {$[62-66]$} \\
\hline
\end{tabular}

N.R, not reported; $\mathrm{MeOH}$, Methanol; $\mathrm{Fe}_{3} \mathrm{O}_{4} \mathrm{NPs}, \mathrm{Fe}_{3} \mathrm{O}_{4}$ nanoparticles; MO, Methyl orange; MB, Methylene blue; RB, Rhodamine B; CR, Congo red; MV, Methyl violet; AB-10, Amido black 10B; F, Fluoride; BBY, Bismarck brown Y; CV, Crystal violet; SO, Safranin O; NFX, Norfloxacin; AG25, Acid Green 25; RR-120, Reactive red 120; PO, Procion orange; DR23, Direct red 23; DR80, Direct red 80; RB-114, Reactive blue 114; MG, Malachite green CFA, Clofibric acid; CBZ, Carbamazepine; Tet, Tetracycline; PZC, point of zero charge; EDS, Energy dispersive $\mathrm{X}$-ray spectroscopy; XPS, X-ray photoelectron spectroscopy; XAS, X-ray absorption spectroscopy; XRD, X-ray diffraction; ZP, zeta potential; FESEM, Field Emission Scanning Electron Microscope; BSLLD, back-scattered laser light diffraction; TGA, Thermogravimetric analysis; ESR, Electron spin resonance spectroscopy; SAXS, Small-angle $\mathrm{X}$-ray scattering; TEM, Transmission electron microscopy; MP, mercury porosimetry.

Mango is another abundant fruit grown in tropical and subtropical regions across the world; unfortunately, the peel constitutes $7-24 \%$ of the fruit's weight and is not a recyclable byproduct. For this reason, mango peel waste was evaluated as an adsorbent for Cd(II) and $\mathrm{Pb}$ (II) ions. It was oven-dried at $70{ }^{\circ} \mathrm{C}$, ground and sieved until obtaining a particle size of 0.85-1.0 mm [78]. Another interesting fruit waste used to remove Cd(II), Cr(III), and Zn(II) from water was the kiwi peel, ground to two particle sizes of $1 \mathrm{~mm}$ and $2 \mathrm{~mm}$ and treated with $\mathrm{NaOH}$ [77]. Tangerine peel processed in the same way proved to be an excellent source of biomass for the removal of these metals from surface and groundwater due to its chemical composition, which is rich in cellulose and other polysaccharides [77,94]. Šćiban, et al. [73] evaluated the efficiency of soybean straw, wheat straw, corn stalks, and corn cobs for the adsorption of $\mathrm{Cu}, \mathrm{Ni}, \mathrm{Cd}$, and $\mathrm{Pb}$ from wastewater both with formaldehyde, $\mathrm{NaOH}$ and $\mathrm{H}_{2} \mathrm{SO}_{4}$ modification and without chemical modification. In another study, Amer et al. [16] dried and ground rice straw into different particle sizes and found the 75-150 $\mu \mathrm{m}$ size to be the most optimal for $\mathrm{Pb}$ removal. Sugar cane baggage (SCB) and beet pulp have been tested as effective adsorbents for other heavy metals such as Fe(III), Zn(II), Co(II), and $\mathrm{Mn}(\mathrm{II})$. These biowastes were soaked in $\mathrm{NaOH}$ and $\mathrm{CH}_{3} \mathrm{COOH}$ to remove hydroxide traces before being dried, powdered, and sieved to an average particle size of $0.75 \mathrm{~mm}[86,88]$. SCB was evaluated in raw conditions and after chemical pre-treatment with hydrochloric acid; the latter had a significant positive effect on its capacity to remove $\mathrm{Mn}$ (II) [87]. Other studies have evaluated black tea and mixed tea wastes as low-cost adsorbents for the removal of several heavy metals; for instance, sulphonate-treated tea waste was an effective biosorbent for the removal of $\mathrm{Cr}(\mathrm{VI}), \mathrm{MB}$, and tetracycline [90-93]. Different amounts of Fe, $\mathrm{Mn}, \mathrm{Zn}, \mathrm{Ni}, \mathrm{Cu}$, and $\mathrm{Cd}$ were removed from aqueous solutions by employing a biosorbent from sunflower stalks and leaves, both without pretreatment and activated with $\mathrm{NaOH}$ to improve Ni adsorption [89]. 
Bioadsorbents have been implemented as one possible solution to solve the problem of colored wastewater discharges from the textile industry. For example, durian peel was collected as solid waste and used directly for the uptake of acid green 25. Durian peels were ground and screened to a particle size range of 351 to $589 \mu \mathrm{m}$ before being treated with $\mathrm{HCl}$ and dried at $80^{\circ} \mathrm{C}$ [74]. Another excellent adsorbent to remove dyes such as crystal violet $(\mathrm{CV})$ is non-pretreated grapefruit peel, which is first separated from leaves, twigs, and other debris that interfere into the adsorption process and then dried at $70{ }^{\circ} \mathrm{C}$, ground, and sieved to a particle size of $0.85-1.0 \mathrm{~mm}$ [75]. Etim et al. [72] employed coconut coir dust without chemical modification to remove $\mathrm{MB}$, resulting in $\mathrm{pH}$-dependent monolayer adsorption behavior. Hameed [76] studied the MB adsorption process employing a jackfruit peel biobed. This biowaste was sliced and dried at $70{ }^{\circ} \mathrm{C}$, then ground and sieved to obtain a particle size range of $0.5-1 \mathrm{~mm}$. Banana, orange, and pomelo peels represent another low-cost method, adsorbing MB and other dye pollutants such as methyl orange, rhodamine- $\mathrm{B}$, congo red, methyl violet, amido black $10 \mathrm{~B}$, procion orange, violet 17 (V-17), direct red 23, direct red 80, and reactive blue 114 without requiring chemical treatment. The waste peels in these studies were dried in the sunlight and a hot air oven at 60 or $120^{\circ} \mathrm{C}$, and the resulting material was crushed with a mill and sieved to obtain a particle size $<500 \mu \mathrm{m}[67,80,81,83,95,96]$.

Low-cost adsorbents derived from herbage and forage have been studied for the removal of dyes generated from different industries. Cauliflower leaves were dried and pulverized to achieve a higher adsorption capacity for $\mathrm{MB}$ in synthetic aqueous solutions [70]. Gupta et al. [84] evaluated the leaves and stems from potato plants as biodegradable material for the removal of $\mathrm{MB}$ and malachite green; leaves boiled and dried at $60^{\circ} \mathrm{C}$ showed better adsorption efficiency than stems for both dyes at same particle sizes (100-150 $\mu \mathrm{m})$. Baldikova et al. [69] employed raw and chemically, magnetically, and non-magnetically modified versions of barley straw to remove four water-soluble dyes (bismarck brown $\mathrm{Y}$, crystal violet, $\mathrm{MB}$, and safranin $\mathrm{O}$ ). The barley straw was cut and sieved into fine particles ( 0.15-2 mm diameter) and a fraction was magnetically modified by microwavesynthetized magnetic iron oxides followed by treatment with citric acid, then dried at $50{ }^{\circ} \mathrm{C}$ until reaching a constant weight.

Macro- and micronutrients that alter the microbial dynamics in ecosystems have been removed by employing bioadsorbents. Fluoride, one of these pollutants, was removed from contaminated underground water using natural banana-peel powder in a fixed-bed design. This biomaterial was dried at 50 and $60^{\circ} \mathrm{C}$ and then ground to obtain a particle size of $200 \mu \mathrm{m}$ for the batch experiments [68]. Mangosteen pericarps, passion fruit rinds, red onion peels, and red dragon fruit peels were used to make an anthocyanin-based adsorbent to attract iodide ions $\left(\mathrm{I}^{-}\right)$. These raw materials were dried at $60{ }^{\circ} \mathrm{C}$, ground, and sieved to obtain particles of $0.5-0.711 \mathrm{~mm}$ [79]. Additionally, phosphates were extracted employing peanut husk improved with $\mathrm{Fe}_{3} \mathrm{O}_{4}$ as an adsorption assistant, as this increases ionic attraction and provides a cheaper recovery method than centrifugation or filtration. This oxide was combined with iminodiacetic acid (IA) and zirconium ( $\mathrm{Zr}$ ) to increase the efficiency and selectivity of the peanut husk-based magnetic material [82].

As for pharmaceuticals, coffee and rice husks were tested by Paredes-Laverde et al. [71] in a variety of particle sizes (from $<75$ to $500 \mu \mathrm{m}$ ) to retain the antibiotic norfloxacin in distilled and municipal water. Both natural adsorbents were dried at $60{ }^{\circ} \mathrm{C}$, ground to powder, and sieved; particles $<75 \mu \mathrm{m}$ proved to be the best option for norfloxacin adsorption. Another cereal byproduct, rice straw, was dried at the same temperature, pulverized, and passed through a mesh sieve $(<150 \mu \mathrm{m})$ to test its ability to remove clofibric acid and carbamazepine from aqueous solutions at different $\mathrm{pH}$ values and adsorbent concentrations [85]. 


\section{Characterization of Bioadsorbents}

There are several characterization techniques used to understand the physical and chemical properties of materials, their adsorption capacity, and their interactions with pollutants; these include scanning electron microscopy (SEM), the Brunauer-Emmett-Teller method (BET), the Barrett-Joyner-Halenda method (BJH), Fourier transform infrared spectroscopy (FTIR), and energy-dispersive X-ray (EDX), among others. Adsorbents from fruits, vegetables, grains, seeds, herbage, and forage wastes have mainly been characterized by applying FTIR (Tables 1 and 2). This technique makes it possible to identify the molecules and functional groups on the surface of the biomaterials [51] that interact with the contaminants. Some of these correspond to hydroxyl groups generated by the cellulose, hemicellulose, and lignin present in agricultural waste [42]. An SCB-based adsorbent was characterized using this analysis to demonstrate the presence of hydroxyl, $\mathrm{C}-\mathrm{H}, \mathrm{C}-\mathrm{O}$, and $-\mathrm{OCH}_{3}$ groups as well as other oxygen-containing functional groups on its surface [86]. The structure of mango peel waste was analyzed by FTIR spectroscopy, demonstrating that carboxyl and hydroxyl groups were the main groups responsible for sorption of metals [10,78]. Yadav et al. [49] used this characterization method to evaluate the adsorbent obtained from rice husk and lemon juice residues, showing that $\mathrm{O}-\mathrm{H}, \mathrm{N}-\mathrm{O}$, and $\mathrm{C}-\mathrm{N}$ groups bind to phosphates. All the biowastes and adsorbents reported here have been analyzed using this technique except for peach stones, sunflower leaves/stalks, and several others not characterized by any analytical method (coir pith, corn cob and stalk, soybean, wheat straw, kiwi, tangerine peels, and jackfruit peels). Peach stones were characterized by $\mathrm{N}_{2} / \mathrm{CO}_{2}$ adsorption, point of zero charge, and thermal analysis, whereas sunflower residues were characterized by SEM and point of zero charge. The $\mathrm{pH}$ at the point of zero charge indicates that above or below that value the net surface charge of the adsorbent is predominantly negative or positive, respectively. Gas adsorption and SEM studies have revealed that peach stone-derived AC presents different pore features and that sunflower leaves/stalks have an agglomerated shape with a porous, heterogeneous, and uneven structure [54,89].

Another, less conventional method is Vibrating-sample magnetometry, which involves the vibration of magnetic materials operating under Faraday's Law, using sensing coils to detect the difference in the voltage variation in proportion to the magnetic moment of the sample [97]. A magnetic peanut husk adsorbent was characterized with this technique, allowing the observation of its properties before and after phosphate adsorption and its recovery using a magnet for practical applications [82]. Other analytical techniques include Zeta potential, X-ray photoelectron spectroscopy, and X-ray absorption spectroscopy. The first technique was employed to determine the electrostatic affinity for $\mathrm{Pb}$ (II) and the dye reactive blue 114 on the surface of magnetic coffee waste and pomelo peel sorbents [28,83], whereas X-ray photoelectron spectroscopy, and X-ray absorption spectroscopy were used to study the iodine form, oxidation state, and structure of adsorbents derived from mangosteen pericarps, passion fruit rinds, red onion peels, and red dragon fruit peels [79].

Brunauer-Emmett-Teller and Barrett-Joyner-Halenda (BET/BJH) are techniques employed to estimate certain surface characteristics of bioadsorbents such as area, pore size, and volume [45]. BET uses the equilibrium adsorption isotherm at the adsorbate boiling point, whereas $\mathrm{BJH}$ uses an inverse relation between pore radius and multilayer thickness [98]. BJH was used to determine the micropore and mesopore volume of pineapple waste-based AC, obtaining values of $289 \mathrm{~m}^{2} / \mathrm{g}$ and $253 \mathrm{~m}^{2} / \mathrm{g}$ respectively. Both types of pores enlarge the surface area, resulting in better adsorption because ion interactions occur more smoothly [48]. BET permits before and after comparisons of any modifications, aiding understanding of ion integration in the adsorption process; for example, the reduction of the surface area by the element zirconium in a peanut husk adsorbent [82]. This method was chosen to characterize a banana peel adsorbent with a surface area of $13 \mathrm{~m}^{2} / \mathrm{g}$, which indicates a small pore size [60]. AC derived from coconut buttons and rice straw biosorbents were characterized by BET; the former had a surface area of $479 \mathrm{~m}^{2} / \mathrm{g}$, evidencing a wider pore size distribution and better adsorption capacity, whereas the rice straw presented a specific surface area of $1.95 \mathrm{~m}^{2} / \mathrm{g}$ and average pore size of $12.1 \mathrm{~nm}[16,37]$. As can be seen 
in Tables 1 and 2, the majority of adsorbents and raw materials have been analyzed by $\mathrm{BET}$ and/or BJH, including Acacia erioloba seeds, Aegle marmelos shell, Argania spinosa tree nut shells, cacao shells, siriguela seeds, peanut shell, black tea waste, spent and granular coffee, and papaya, orange, and pomelo peels. These have been additionally characterized using X-ray diffraction, thermogravimetric analysis, differential thermal analysis and thermogravimetry, SEM, field emission scanning electron microscopy, energy-dispersive X-ray, back-scattered laser light diffraction, Raman spectroscopy, electron spin resonance spectroscopy, small-angle X-ray scattering, and the Horvath-Kawazoe method.

SEM is another common characterization technique, and allows identification of the morphology of the bioadsorbents before and after adsorption. It is useful for the simultaneous appreciation of the number and size of pores, as well as the verification of whether a fibrous structure is replaced by a smooth one [50]. An improvement on this method is ultra-high-resolution SEM, which is suitable for the visualization of the surface texture of spent coffee by scanning it with a high-energy beam of electrons with higher sensitivity $[38,99]$. SEM is usually coupled with EDX, as in an analysis performed on mangosteen pericarp adsorbent where the changes in composition and anthocyanin quantity determined the removal efficiency of radioactive iodine [79]. Amer et al. [16] characterized the surface area, pore volume, size, and chemical composition of rice straw with a particle size between 76-150 $\mu \mathrm{m}$ using EDX before and after lead adsorption; EDX showed that the presence of organic elements such as $\mathrm{Na}, \mathrm{Ca}$, and $\mathrm{Mg}$ decreased after heavy metal adsorption, which promoted effective ion exchange and retention of the contaminant. Many other adsorbent materials, including cacao pod husk, palm tree leaves, rubber pod husk, banana peel, barley straw, cauliflower leaves, coffee husk, potato leaves and stem, rice husk, SCB, tamarind seeds, tea mixed waste, and watermelon rinds have been analyzed with SEM-EDX or only SEM (Tables 1 and 2).

\section{Water Treatment Employing Bioadsorbents}

\subsection{Bioadsorbents Based on Grains and Seeds}

\subsubsection{Nutrients and Heavy Metals}

Well-known contaminants in water that need to be continuously monitored include the nutrients nitrogen and phosphorus and the various heavy metals. Aryee et al. [82] studied a bioadsorbent based on peanut husk functionalized with zirconium, iminodiacetic acid, and $\mathrm{Fe}_{3} \mathrm{O}_{4}$ that was able to remove up to $88.5 \%$ of phosphates in six hours at a temperature of $30^{\circ} \mathrm{C}$ and $\mathrm{pH} 3$. The addition of zirconium was crucial due to its interaction with hydroxyl, amines, and carboxyl groups; this enhanced $\mathrm{PO}_{4}{ }^{3-}$ sequestration at the maximum sorption capacity of $13.2 \mathrm{mg} / \mathrm{g}$. Rubber pod husk is another byproduct without commercial value that can serve as an adsorbent to remove phosphates dissolved in water $(0.1-0.5 \mathrm{~g} / \mathrm{L})$, showing favorable results $\left(\mathrm{q}_{\mathrm{m}}=39.9 \mathrm{mg} / \mathrm{g}\right)$ after six hours (contact time) at $\mathrm{pH} 7$ and $29^{\circ} \mathrm{C}$ [50]. Raw tamarind seeds are a residue of interest due to their high content of lignocellulose and surface groups; these change under chemical $\left(\mathrm{H}_{2} \mathrm{SO}_{4}\right)$ and physical (ultrasonic waves) treatment, resulting in $\mathrm{q}_{\mathrm{m}}$ values around $18 \mathrm{mg} / \mathrm{g}$ and a $50 \%$ reduction in the reaction time to adsorb $\mathrm{Pb}$ (II) [32]. Ultrasound-modified residues present a large surface area with large pores and cavities. Additionally, variations in $\mathrm{pH}$ charge the hydroxyl groups, increasing their affinity for positive ions and achieving $99.5 \%$ removal of $\mathrm{Pb}$ (II) at $\mathrm{pH} 6$ and $30^{\circ} \mathrm{C}$ [32]. Edathil et al. [28] analyzed $\mathrm{Pb}(\mathrm{II})$ adsorption by employing a modified magnetic-coffee membrane. The assays of sorption capacity showed better results with $0.025 \mathrm{~g}$ of the nanocomposite at $25^{\circ} \mathrm{C}$ and $\mathrm{pH} 7.3$, removing $99.5 \%$ of the contaminant in $30 \mathrm{~min}$. On the other hand, the non-activated exhausted coffee was able to remove $97.6 \%$ of $\mathrm{Hg}(\mathrm{II})$, adjusting the adsorbent and mercury concentrations to 0.4 and $77.9 \mathrm{mg} / \mathrm{L}$, respectively, with a contact time of $192.4 \mathrm{~min}$ at $33^{\circ} \mathrm{C}$ and $\mathrm{pH} 7$ [55].

Another metal that contaminates water is silver. According to Araújo et al. [56], it is possible to remove up to $99 \%\left(\mathrm{q}_{\mathrm{m}}=23.13 \mathrm{mg} / \mathrm{g}\right)$ of silver using moringa powder thanks to its high protein content which, depending on $\mathrm{pH}$, provides a high amount of charged amine and carboxyl groups. The optimal conditions for Ag retention were obtained using 
an adsorbent with a $<500 \mathrm{~mm}$ particle size and $20 \mathrm{~min}$ of contact time at $\mathrm{pH}$ 6.5. Feizi and Jalali [89] demonstrated the feasible removal of $\mathrm{Fe}, \mathrm{Mn}, \mathrm{Zn}, \mathrm{Ni}, \mathrm{Cu}$, and $\mathrm{Cd}$ from aqueous solutions by implementing raw and modified walnut shells. In general, the maximum sorption capacity for the six metals was $44.1 \pm 18.5 \mathrm{mg} / \mathrm{g}$, while a removal efficiency of $96.5 \%$ was observed only for $\mathrm{Mn}$ at $\mathrm{pH} 8$.

Table 3 summarizes the phosphorus and heavy metals removal efficiencies previously described and the isothermal models that fitted the experimental data; the Langmuir, Freundlich, and pseudo-second order models best explained the adsorption behavior in the biomaterials.

Table 3. Adsorption parameters and removal efficiencies of different biosorbents derived from grains and seeds for the removal of pollutants in aqueous matrices.

\begin{tabular}{|c|c|c|c|c|c|c|}
\hline Biowaste & Contaminant & $\begin{array}{l}\text { Isothermal Model } \\
\text { Adjusted }\end{array}$ & $\begin{array}{l}\text { Kinetic Model } \\
\text { Adjusted }\end{array}$ & $\mathrm{q}_{\mathrm{m}} / \mathrm{q}_{\mathrm{e}}$ & $\begin{array}{l}\text { Removal } \\
\text { Efficiency } \\
(\%)\end{array}$ & Ref. \\
\hline $\begin{array}{c}\text { Argania Spinosa tree } \\
\text { nutshells }\left(\mathrm{TiO}_{2}\right. \\
\text { composite } \mathrm{AC})\end{array}$ & $\begin{array}{l}\text { DFC } \\
\text { CBZ } \\
\text { SMX }\end{array}$ & $\begin{array}{l}\text { Langmuir } \\
\text { Langmuir } \\
\text { Langmuir }\end{array}$ & $\begin{array}{l}\text { Pseudo-first order } \\
\text { Pseudo-first order } \\
\text { Pseudo-first order }\end{array}$ & $\begin{array}{l}153.8 \mathrm{mg} / \mathrm{g} \\
105.3 \mathrm{mg} / \mathrm{g} \\
125.0 \mathrm{mg} / \mathrm{g}\end{array}$ & $\begin{array}{l}100.00 \\
85.00 \\
67.00\end{array}$ & [52] \\
\hline Cacao pod husk & $\mathrm{SD}$ & Freundlich & Pseudo-second order & $5.53 \mathrm{mg} / \mathrm{g}$ & 93.6 & [51] \\
\hline $\begin{array}{c}\text { Cacao shell } \\
\left(\mathrm{H}_{3} \mathrm{PO}_{4} \text {-activated }\right)\end{array}$ & $\begin{array}{l}\alpha \text {-Lac } \\
\text { BSA }\end{array}$ & $\begin{array}{c}\text { Toth } \\
\text { Langmuir }\end{array}$ & $\begin{array}{l}\text { Pseudo-second order } \\
\text { Pseudo-second order }\end{array}$ & $\begin{array}{l}179.91 \mathrm{mg} / \mathrm{g} \\
41.02 \mathrm{mg} / \mathrm{g}\end{array}$ & $\begin{array}{l}91.67 \\
21.25\end{array}$ & [45] \\
\hline $\begin{array}{c}\text { Cacao shell } \\
\text { ( } \mathrm{ZnCl}_{2} \text {-activated) }\end{array}$ & $\begin{array}{l}\alpha-\operatorname{Lac} \\
\text { BSA }\end{array}$ & $\begin{array}{c}\text { Toth } \\
\text { Langmuir }\end{array}$ & $\begin{array}{l}\text { Pseudo-second order } \\
\text { Pseudo-second order }\end{array}$ & $\begin{array}{l}141.69 \mathrm{mg} / \mathrm{g} \\
147.84 \mathrm{mg} / \mathrm{g}\end{array}$ & $\begin{array}{l}70.33 \\
86.86\end{array}$ & [45] \\
\hline Coffee husk & NFX & $\begin{array}{l}\text { Langmuir and } \\
\text { Redlich-Peterson }\end{array}$ & Pseudo-second order & $33.56 \mathrm{mg} / \mathrm{g}$ & 99.66 & [71] \\
\hline Exhausted coffee & $\mathrm{Hg}(\mathrm{II})$ & Langmuir & Pseudo-second order & $31.75 \mathrm{mg} / \mathrm{g}$ & 97.69 & [55] \\
\hline $\begin{array}{l}\text { Magnetic coffee waste } \\
\left(\mathrm{Fe}_{3} \mathrm{O}_{4} \mathrm{NPs}\right)\end{array}$ & $\mathrm{Pb}(\mathrm{II})$ & Langmuir & Pseudo-second order & $48.78 \mathrm{mg} / \mathrm{g}$ & 99.56 & [28] \\
\hline Moringa oleifera seeds & $\begin{array}{c}\mathrm{Ag}(\mathrm{I}) \\
\mathrm{RR}-120\end{array}$ & $\begin{array}{l}\text { Langmuir } \\
\text { Langmuir and Freundlich }\end{array}$ & $\begin{array}{c}\text { N.R } \\
\text { Pseudo-second order }\end{array}$ & $\begin{array}{l}23.13 \mathrm{mg} / \mathrm{g} \\
413.32 \mathrm{mg} / \mathrm{g}\end{array}$ & $\begin{array}{l}99.00 \\
\text { N.R }\end{array}$ & {$[56]$} \\
\hline $\begin{array}{c}\text { Peanut husk } \\
\text { (Magnetic husk) }\end{array}$ & Phosphates & Freundlich & Elovich & $13.2 \mathrm{mg} / \mathrm{g}$ & 88.5 & [82] \\
\hline Peanut shell & AY-36 & Langmuir and Freundlich & Pseudo-second order & $66.7 \mathrm{mg} / \mathrm{g}$ & 98.55 & [42] \\
\hline Raw tamarind seeds & $\mathrm{Pb}$ (II) & Langmuir & Pseudo-first order & $16.0 \mathrm{mg} / \mathrm{g}$ & 99.52 & [32] \\
\hline Rice husk & NFX & $\begin{array}{l}\text { Langmuir and } \\
\text { Redlich-Peterson }\end{array}$ & Pseudo-second order & $20.12 \mathrm{mg} / \mathrm{g}$ & 96.95 & [71] \\
\hline Rubber pod husk & Phosphates & Freundlich & Pseudo-second order & $39.98 \mathrm{mg} / \mathrm{g}$ & N.R & [50] \\
\hline $\begin{array}{l}\text { Siriguela seeds } \\
\left(\mathrm{ZnCl}_{2} \text {-activated }\right)\end{array}$ & $\begin{array}{c}\alpha-\operatorname{Lac} \\
\text { BSA }\end{array}$ & $\begin{array}{c}\text { Toth } \\
\text { Langmuir }\end{array}$ & $\begin{array}{l}\text { Pseudo-second order } \\
\text { Pseudo-second order }\end{array}$ & $\begin{array}{l}173.05 \mathrm{mg} / \mathrm{g} \\
188.29 \mathrm{mg} / \mathrm{g}\end{array}$ & $\begin{array}{l}87.42 \\
92.29 \\
\end{array}$ & [45] \\
\hline $\begin{array}{c}\text { Siriguela seeds } \\
\left(\mathrm{H}_{3} \mathrm{PO}_{4} \text {-activated }\right)\end{array}$ & $\begin{array}{l}\alpha-\operatorname{Lac} \\
\text { BSA }\end{array}$ & $\begin{array}{c}\text { Toth } \\
\text { Langmuir } \\
\end{array}$ & $\begin{array}{l}\text { Pseudo-second order } \\
\text { Pseudo-second order }\end{array}$ & $\begin{array}{l}193.54 \mathrm{mg} / \mathrm{g} \\
130.31 \mathrm{mg} / \mathrm{g}\end{array}$ & $\begin{array}{l}96.67 \\
81.67\end{array}$ & [45] \\
\hline $\begin{array}{c}\text { Spent coffee ground } \\
\text { (Calcium-alginate beads) }\end{array}$ & $\begin{array}{l}\mathrm{AO7} \\
\mathrm{MB}\end{array}$ & $\begin{array}{l}\text { Sips } \\
\text { Sips }\end{array}$ & $\begin{array}{l}\text { Pore diffusion } \\
\text { Pore diffusion }\end{array}$ & $\begin{array}{l}665.9 \mathrm{mg} / \mathrm{g} \\
986.8 \mathrm{mg} / \mathrm{g}\end{array}$ & $\begin{array}{c}99.90 \\
100\end{array}$ & [44] \\
\hline $\begin{array}{l}\text { Spent coffee waste biochar } \\
\text { (NaOH-activated) }\end{array}$ & $\begin{array}{l}\mathrm{NPX}^{\mathrm{LK}} \\
\mathrm{DCF}^{\mathrm{LK}} \\
\mathrm{IBU}^{\mathrm{LK}} \\
\mathrm{NPX}^{\mathrm{WW}} \\
\mathrm{DCF}^{\mathrm{WW}} \\
\text { IBU }^{\mathrm{WW}}\end{array}$ & $\begin{array}{l}\text { Langmuir } \\
\text { Langmuir } \\
\text { Langmuir } \\
\text { Langmuir } \\
\text { Langmuir } \\
\text { Langmuir }\end{array}$ & $\begin{array}{l}\text { Pseudo-second order } \\
\text { Pseudo-second order } \\
\text { Pseudo-second order } \\
\text { Pseudo-second order } \\
\text { Pseudo-second order } \\
\text { Pseudo-second order }\end{array}$ & $\begin{array}{c}269.01 \mu \mathrm{mol} / \mathrm{g} \\
97.17 \mu \mathrm{mol} / \mathrm{g} \\
76.10 \mu \mathrm{mol} / \mathrm{g} \\
263.34 \mu \mathrm{mol} / \mathrm{g} \\
97.12 \mu \mathrm{mol} / \mathrm{g} \\
74.07 \mu \mathrm{mol} / \mathrm{g}\end{array}$ & $30.7-97.1$ & [38] \\
\hline $\begin{array}{l}\text { Spent coffee waste biochar } \\
\text { (Pristine-activated) }\end{array}$ & $\begin{array}{l}\text { NPX } \\
\text { DCK } \\
\text { IBK } \\
\text { IBU } \\
\text { NPXWW } \\
\text { DCF }^{W W} \\
\text { IBU }^{W W}\end{array}$ & $\begin{array}{l}\text { Freundlich } \\
\text { Freundlich } \\
\text { Freundlich } \\
\text { Freundlich } \\
\text { Freundlich } \\
\text { Freundlich }\end{array}$ & $\begin{array}{l}\text { Pseudo-second order } \\
\text { Pseudo-second order } \\
\text { Pseudo-second order } \\
\text { Pseudo-second order } \\
\text { Pseudo-second order } \\
\text { Pseudo-second order }\end{array}$ & $\begin{array}{c}107.53 \mu \mathrm{mol} / \mathrm{g} \\
91.74 \mu \mathrm{mol} / \mathrm{g} \\
86.21 \mu \mathrm{mol} / \mathrm{g} \\
344.48 \mu \mathrm{mol} / \mathrm{g} \\
202.92 \mu \mathrm{mol} / \mathrm{g} \\
124.14 \mu \mathrm{mol} / \mathrm{g}\end{array}$ & $7.5-10.3$ & [38] \\
\hline Sulfonated coffee waste & $\begin{array}{l}\text { SMX } \\
\text { BPA }\end{array}$ & $\begin{array}{l}\text { Langmuir and Temkin } \\
\text { Temkin }\end{array}$ & $\begin{array}{l}\text { Pseudo-second order } \\
\text { Pseudo-second order }\end{array}$ & $\begin{array}{l}256 \mathrm{mg} / \mathrm{g} \\
271 \mathrm{mg} / \mathrm{g}\end{array}$ & $\begin{array}{l}\text { N.R } \\
\text { N.R }\end{array}$ & [100] \\
\hline Sunflower seed hulls & $\begin{array}{c}\mathrm{MB} \\
\mathrm{AB}-15\end{array}$ & $\begin{array}{l}\text { Langmuir } \\
\text { Langmuir }\end{array}$ & $\begin{array}{l}\text { Pseudo-second order } \\
\text { Pseudo-second order }\end{array}$ & $\begin{array}{l}473.44 \mathrm{mg} / \mathrm{g} \\
430.37 \mathrm{mg} / \mathrm{g}\end{array}$ & $\begin{array}{l}\text { N.R } \\
\text { N.R }\end{array}$ & [31] \\
\hline $\begin{array}{l}\text { Tamarind seeds } \\
\left(\mathrm{H}_{2} \mathrm{SO}_{4} \text {-modified }\right)\end{array}$ & $\mathrm{Pb}(\mathrm{II})$ & Langmuir & Pseudo-first order & $18.34 \mathrm{mg} / \mathrm{g}$ & 99.52 & [32] \\
\hline
\end{tabular}


Table 3. Cont.

\begin{tabular}{|c|c|c|c|c|c|c|}
\hline Biowaste & Contaminant & $\begin{array}{l}\text { Isothermal Model } \\
\text { Adjusted }\end{array}$ & $\begin{array}{l}\text { Kinetic Model } \\
\text { Adjusted }\end{array}$ & $\mathrm{q}_{\mathrm{m}} / \mathrm{q}_{\mathrm{e}}$ & $\begin{array}{l}\text { Removal } \\
\text { Efficiency } \\
(\%)\end{array}$ & Ref. \\
\hline $\begin{array}{c}\text { Tamarind seeds } \\
\text { (Ultrasound-modified) }\end{array}$ & $\mathrm{Pb}(\mathrm{II})$ & Langmuir & Pseudo-first order & $18.86 \mathrm{mg} / \mathrm{g}$ & 99.52 & {$[32]$} \\
\hline Walnut shell & $\begin{array}{l}\mathrm{Mn}(\mathrm{II}) \\
\mathrm{Zn} \\
\mathrm{Fe} \\
\mathrm{Cd} \\
\mathrm{Cu} \\
\mathrm{Ni}\end{array}$ & $\begin{array}{l}\text { Langmuir } \\
\text { Langmuir } \\
\text { Langmuir } \\
\text { Langmuir } \\
\text { Langmuir } \\
\text { Langmuir }\end{array}$ & $\begin{array}{l}\text { Pseudo-second order } \\
\text { Pseudo-second order } \\
\text { Pseudo-second order } \\
\text { Pseudo-second order } \\
\text { Pseudo-second order } \\
\text { Pseudo-second order }\end{array}$ & $\begin{array}{l}28.6 \mathrm{mg} / \mathrm{g} \\
33.3 \mathrm{mg} / \mathrm{g} \\
62.6 \mathrm{mg} / \mathrm{g} \\
76.9 \mathrm{mg} / \mathrm{g} \\
38.8 \mathrm{mg} / \mathrm{g} \\
29.4 \mathrm{mg} / \mathrm{g}\end{array}$ & $\begin{array}{l}96.5 \\
\text { N.R } \\
\text { N.R } \\
\text { N.R } \\
\text { N.R } \\
\text { N.R }\end{array}$ & [89] \\
\hline $\begin{array}{c}\text { Walnut shell } \\
\text { (NaOH-modified) }\end{array}$ & $\mathrm{Ni}$ & Langmuir & Pseudo-second order & $38.9 \mathrm{mg} / \mathrm{g}$ & N.R & [89] \\
\hline \multirow[t]{2}{*}{$\begin{array}{l}\text { Waste coffee grounds } \\
\text { ( } \mathrm{CO}_{2} \text {-activated carbon) }\end{array}$} & $\begin{array}{l}\mathrm{MB} \\
\mathrm{MO}\end{array}$ & $\begin{array}{l}\text { Langmuir } \\
\text { Langmuir }\end{array}$ & $\begin{array}{l}\text { Pseudo-second order } \\
\text { Pseudo-second order }\end{array}$ & $\begin{array}{l}678 \mathrm{mg} / \mathrm{g} \\
612 \mathrm{mg} / \mathrm{g}\end{array}$ & $\begin{array}{l}\text { N.R } \\
\text { N.R }\end{array}$ & [101] \\
\hline & $\begin{array}{l}\text { N.R, not } \\
\text { CBZ, Carl } \\
\text { albumin; } \\
\text { blue; NP) } \\
\text { Naproxer } \\
\text { AB-15, Ac }\end{array}$ & $\begin{array}{l}\text { d; } \mathrm{q}_{\mathrm{m}} \text {, Maximum sc } \\
\text { epine; SMX, Sulfame } \\
\text { Jorfloxacin; RR-120, } \\
\text { Japroxen lake water } \\
\text { ewater; DCFWW, D } \\
\text { e 15; MO, Methyl or }\end{array}$ & $\begin{array}{l}\text { n capacity; qe, Adsorpt } \\
\text { zole; SD, Sodium diclofe } \\
\text { ve red } 120 ; \mathrm{AY}-36 \text {, Metar } \\
\text { FLK, Diclofenac lake w } \\
\text { nac wastewater; IBUW } \\
\mathrm{Fe}_{3} \mathrm{O}_{4} \mathrm{NPs}_{2} \mathrm{Fe}_{3} \mathrm{O}_{4} \text { nano }\end{array}$ & $\begin{array}{l}\text { capacity at eq } \\
\alpha \text {-Lac, } \alpha \text {-Lact } \\
\text { llow; AO7, A } \\
\text { IBULK, Ibup } \\
\text { ouprofen was } \\
\text { cles. }\end{array}$ & $\begin{array}{l}\text { um; DFC, D } \\
\text { n; BSA, Bovi } \\
\text { nge 7; MB, N } \\
\text { lake water; } \\
\text { r; BPA, Bis! }\end{array}$ & $\begin{array}{l}\text { fenac; } \\
\text { serum } \\
\text { nylene } \\
\text { XWW, } \\
\text { nol A; }\end{array}$ \\
\hline
\end{tabular}

\subsubsection{Industrial Contaminants}

Although a wide variety of industrial contaminants exist in water sources, the main substances that have been removed by employing adsorbents derived from grains and seeds are dyes, bisphenol A, and industrial proteins such as BSA and $\alpha$-Lac (Table 3). Garg et al. [42] used peanut shell AC to adsorb the azo dye metanil yellow in a spontaneous and endothermic process at $35^{\circ} \mathrm{C}$ by adding biochar at an adsorbent/contaminant ratio of 20:1 at $\mathrm{pH}$ 2. The chemical association of the dye molecules with the nitrogen and sulfur groups present in the adsorbent material contributed to the highest removal efficiency (98.55\%). The Langmuir, Freundlich, and pseudo-second kinetics models were chosen to represent the adsorption dynamics. In the same year, Çelekli et al. [57] reported interaction between moringa residues (amino, carbonyl, and amide groups) and reactive red 120 dye, reaching the maximum adsorption equilibrium of $413.32 \mathrm{mg} / \mathrm{g}$ (Langmuir isotherm) in $30 \mathrm{~min}$ at $50{ }^{\circ} \mathrm{C}$ and $\mathrm{pH} 1$. Thermodynamic analysis revealed that the adsorption process was spontaneous. Other organic dyes such as $\mathrm{MB}$ and methyl orange have been retained with high adsorption capacity ( $\mathrm{q}_{\mathrm{e}}=678 \mathrm{mg} / \mathrm{g}$ and $612 \mathrm{mg} / \mathrm{g}$, respectively) in biochar from waste coffee grounds activated by $\mathrm{CO}_{2}$ [101] or pyrolysis to remove acid orange 7 $\left(\mathrm{q}_{\mathrm{m}}=665.9 \mathrm{mg} / \mathrm{g}\right)$ [44]. Interestingly, this last material can be recycled and used for at least seven cycles at a temperature of $20^{\circ} \mathrm{C}$. Foo and Hameed [31] modeled acid blue 15 and MB adsorption behavior in a sunflower seed hull-based bioadsorbent, obtaining the best result by implementing the Langmuir model $\left(\mathrm{q}_{\mathrm{m}}=430.3 \mathrm{mg} / \mathrm{g}\right.$ and $473.4 \mathrm{mg} / \mathrm{g}$ respectively), and suggested that the adsorbed layer on the AC is only one molecule thick. It is worth mentioning the advantage of the capacity to simultaneously retain anionic (acid blue 15) and cationic (MB) dyes at $30^{\circ} \mathrm{C}$.

The high toxicity of the chemical substances used in the synthesis of plastics and resins (e.g., bisphenol A) has drawn the attention of researchers seeking to eliminate them from water matrices; one alternative is an adsorbent based on coffee waste. Although no removal efficiencies have been reported, sulfonated coffee waste showed a biosorption capacity of $271 \mathrm{mg} / \mathrm{g}$ for bisphenol A at room temperature [100]. Pereira et al. [45] studied the capture of BSA and $\alpha$-Lac by employing AC based on siriguela seeds and cacao shells. Although the adsorption of both whey proteins was evaluated under the same conditions (200 mg/L protein solution, $5 \mathrm{mg} \mathrm{AC}$, room temperature, $\mathrm{pH}$ 7) the retention capacity remained constant over different times ( $16 \mathrm{~h}$ and $3 \mathrm{~h}$, respectively), presenting removal efficiencies that varied between $70.3-96.6 \%$ for $\alpha$-Lac and $21.2-92.2 \%$ for BSA. The Temkin, Freundlich, Toth, and Langmuir models most efficiently represented the adsorption data for coffee waste, siriguela seeds, and cacao shells. 


\subsubsection{Pharmaceuticals}

The removal of the antibiotic norfloxacin in real water samples was tested using rice and coffee husks with similar conditions and particle sizes [71]. The results showed that the maximum removal was achieved in distilled water (96.9 and 99.6\%) after $1 \mathrm{~h}$ at $\mathrm{pH} 6.2$, rather than in municipal samples (81.4 and 95.6\%). Particularly, the highest $\mathrm{q}_{\mathrm{m}}$ value was observed for coffee husk (33.56 vs. $20.12 \mathrm{mg} / \mathrm{g}$ ). Another pharmaceutical recovered from the water with an alternative biosorbent was sulfamethoxazole, which is commonly used to treat bacterial infections. The biological adsorbent consisted of carbonized and sulfonated coffee wastes, and although no removal efficiency was reported it exhibited higher sulfamethoxazole biosorption capacity $(256 \mathrm{mg} / \mathrm{g})$ at room temperature [100]. Spent coffee biochar $\left(\mathrm{NaOH}\right.$-activated) displayed efficient interactions with naproxen $\left(\mathrm{q}_{\mathrm{m}}=263.3\right.$ and $269 \mu \mathrm{mol} / \mathrm{g})$, diclofenac $\left(\mathrm{q}_{\mathrm{m}}=97.1 \mu \mathrm{mol} / \mathrm{g}\right)$, and ibuprofen $\left(\mathrm{q}_{\mathrm{m}}=74.0\right.$ and $\left.76.1 \mu \mathrm{mol} / \mathrm{g}\right)$ in lake water and wastewater effluent at $\mathrm{pH} 7$ and $25{ }^{\circ} \mathrm{C}$ [38]. The pristine activation of this biomaterial improved the adsorptive removal of naproxen $(344.4 \mu \mathrm{mol} / \mathrm{g})$ and diclofenac $(202.9 \mu \mathrm{mol} / \mathrm{g})$ in wastewater, as well as ibuprofen in lake water $(86.2 \mu \mathrm{mol} / \mathrm{g})$ and wastewater $(124.1 \mu \mathrm{mol} / \mathrm{g})$. The complete recovery $(100 \%)$ of diclofenac through a $\mathrm{TiO}_{2}$ composite obtained from Argania Spinosa tree nut shells was found to follow the Langmuir and pseudo-first order models for $50 \mathrm{mg} / \mathrm{L}$ analgesic and $0.1 \mathrm{~g} / \mathrm{L}$ adsorbent at $25{ }^{\circ} \mathrm{C}$ [52]. In this study, carbamazepine and sulfamethoxazole were taken up using the same biomaterial with lower removal efficiencies (85 and 67\% respectively) and adsorption capacities (105.3 and $125 \mathrm{mg} / \mathrm{g}$ respectively) under the same experimental conditions. Sodium diclofenac was retained using AC from cacao pod husk, with an efficiency of $76 \%$; this value increased to $93.6 \%$ when decreasing biochar dosage $(0.25 \mathrm{~g})$ and increasing adsorbate concentration at neutral $\mathrm{pH}$ [51]. As shown in Table 3, the adsorption kinetics for these pharmaceuticals followed the pseudo-second order reactions and other isotherm models, as well as Langmuir.

\subsection{Bioadsorbents Based on Fruits and Vegetables}

\subsubsection{Heavy Metals}

Biosorbents have proven to be a cheap and effective alternative for the removal of heavy metals in polluted water thanks to their high capacity and selectivity for metal ions [102]. Removal efficiencies for $\mathrm{Cu}$ (II) and other heavy metals employing adsorbents derived from fruits and vegetables are presented in Table 4, including the most suitable kinetic and isothermal models. Bhattacharjee et al. [3] reviewed watermelon rinds as a copper adsorbent, reporting removal efficiencies between $58.4 \%$ and $88 \%$. An increase in adsorption capacity was observed as the temperature approached the optimal drying temperature $\left(120^{\circ} \mathrm{C}\right)$, which increased the presence of active sites. Another fruit-based adsorbent that showed a high removal percentage of copper ions (78.8\%) was pomegranate peel [103]; four models were considered for the analysis of its adsorption behavior, Langmuir, Freundlich, Dubinin-Radushkevic, and Temkin. These indicated the maximum pomegranate peel adsorption capacity at $30.12 \mathrm{mg} / \mathrm{g}$; the heavy metal was indirectly adsorbed as a mono- or multilayer on a heterogeneous and porous surface [103]. AC derived from coconut buttons efficiently retained $\mathrm{Cu}(\mathrm{II}), \mathrm{Pb}(\mathrm{III})$, and $\mathrm{Hg}(\mathrm{II})$, with adsorption capacities $\left(\mathrm{Q}^{\circ}\right)$ from 76.3 to $97.7 \mathrm{mg} / \mathrm{g}$ under batch conditions at two $\mathrm{pH}$ values (6 and 7) [37]. Kumar et al. [104] obtained removal percentages of $99.7 \%$ for $\mathrm{Cu}$ (II) from industrial wastewater by implementing raw corn cob at $\mathrm{pH} 5$ and $40^{\circ} \mathrm{C}$ with a contact time of $60 \mathrm{~min}$. The maximum adsorption capacity was $6.24 \mathrm{mg} / \mathrm{g}$ (Langmuir isotherm) following pseudo-second order kinetics. 
Table 4. Adsorption parameters and removal efficiencies of different biosorbents derived from fruit and vegetables for the removal of pollutants in aqueous matrices.

\begin{tabular}{|c|c|c|c|c|c|c|}
\hline Biowaste & Contaminant & $\begin{array}{c}\text { Isothermal } \\
\text { Model Adjusted }\end{array}$ & $\begin{array}{c}\text { Kinetic } \\
\text { Model Adjusted }\end{array}$ & $\mathrm{q}_{\mathrm{m}} / \mathbf{Q}^{\circ}$ & $\begin{array}{c}\text { Removal } \\
\text { Efficiency (\%) }\end{array}$ & Ref. \\
\hline Aegle marmelos shell & IBU & Freundlich & Pseudo-second order & $5 \mathrm{mg} / \mathrm{g}$ & 90 & [53] \\
\hline $\begin{array}{l}\text { Aegle marmelos shell } \\
\text { (Steam-activated) }\end{array}$ & IBU & Langmuir & Pseudo-second order & $12.65 \mathrm{mg} / \mathrm{g}$ & 95 & [53] \\
\hline Banana peel & $\begin{array}{c}\text { MO } \\
\mathrm{MB} \\
\mathrm{RB} \\
\mathrm{CR} \\
\mathrm{MV} \\
\text { AB-10B } \\
\text { Fluoride }\end{array}$ & $\begin{array}{l}\text { Freundlich } \\
\text { Freundlich } \\
\text { Freundlich } \\
\text { Freundlich } \\
\text { Freundlich } \\
\text { Freundlich } \\
\text { N.R }\end{array}$ & $\begin{array}{c}\text { Pseudo-first order } \\
\text { Pseudo-first order } \\
\text { Pseudo-first order } \\
\text { Pseudo-first order } \\
\text { Pseudo-first order } \\
\text { Pseudo-first order } \\
\text { N.R }\end{array}$ & $\begin{array}{l}17.2 \mathrm{mg} / \mathrm{g} \\
15.9 \mathrm{mg} / \mathrm{g} \\
13.2 \mathrm{mg} / \mathrm{g} \\
11.2 \mathrm{mg} / \mathrm{g} \\
7.9 \mathrm{mg} / \mathrm{g} \\
7.9 \mathrm{mg} / \mathrm{g} \\
8.15 \mathrm{mg} / \mathrm{g}\end{array}$ & $\begin{array}{l}\text { N.R } \\
\text { N.R } \\
\text { N.R } \\
\text { N.R } \\
\text { N.R } \\
\text { N.R } \\
86.5\end{array}$ & {$[10,67,68]$} \\
\hline \multirow{2}{*}{$\begin{array}{l}\text { Banana peel } \\
\text { (MeOH/HCl- } \\
\text { treated) }\end{array}$} & $\mathrm{Cd}(\mathrm{II})$ & \multirow{2}{*}{$\begin{array}{c}\text { Langmuir } \\
\text { Langmuir and } \\
\text { Dubinin-Radushkevic }\end{array}$} & Pseudo-first order & $35.52 \mathrm{mg} / \mathrm{g}$ & 95 & \multirow[b]{2}{*}[60,61]{} \\
\hline & $\mathrm{Cr}(\mathrm{VI})$ & & Pseudo-first order & $131.56 \mathrm{mg} / \mathrm{g}$ & 98 & \\
\hline $\begin{array}{c}\text { Beet Pulp } \\
\text { (NaOH-treated) }\end{array}$ & $\mathrm{Mn}(\mathrm{II})$ & N.R & Pseudo-second order & N.R & 86.36 & [88] \\
\hline $\begin{array}{l}\text { Coconut buttons } \\
\left(\mathrm{H}_{2} \mathrm{SO}_{4} \text {-treated }\right)\end{array}$ & $\begin{array}{l}\mathrm{Pb}(\mathrm{II}) \\
\mathrm{Hg}(\mathrm{II}) \\
\mathrm{Cu}(\mathrm{II})\end{array}$ & $\begin{array}{l}\text { Freundlich } \\
\text { Freundlich } \\
\text { Freundlich }\end{array}$ & $\begin{array}{l}\text { Pseudo-second order } \\
\text { Pseudo-second order } \\
\text { Pseudo-second order }\end{array}$ & $\begin{array}{l}97.72 \mathrm{mg} / \mathrm{g} \\
78.84 \mathrm{mg} / \mathrm{g} \\
73.6 \mathrm{mg} / \mathrm{g}\end{array}$ & $\begin{array}{l}98.7 \\
95.8 \\
90.6\end{array}$ & [37] \\
\hline \multirow{4}{*}{ Coconut coir pith } & $\begin{array}{l}\mathrm{Co}(\mathrm{II}) \\
\mathrm{Cr}(\mathrm{III}) \\
\mathrm{Ni}(\mathrm{II})\end{array}$ & $\begin{array}{l}\text { Langmuir } \\
\text { Langmuir } \\
\text { Langmuir }\end{array}$ & $\begin{array}{l}\text { Pseudo-second order } \\
\text { Pseudo-second order } \\
\text { Pseudo-second order }\end{array}$ & $\begin{array}{l}12.82 \mathrm{mg} / \mathrm{g} \\
11.56 \mathrm{mg} / \mathrm{g} \\
15.95 \mathrm{mg} / \mathrm{g}\end{array}$ & $\begin{array}{l}49.64-85.4 \\
46.08-98.2 \\
62.88-98\end{array}$ & \multirow{4}{*}{$\begin{array}{c}{[10,46,47,} \\
59]\end{array}$} \\
\hline & $\mathrm{RB}$ & $\begin{array}{l}\text { Langmuir and } \\
\text { Freundlich }\end{array}$ & Pseudo-first order & $2.56 \mathrm{mg} / \mathrm{g}$ & $43.6-79.4$ & \\
\hline & AV & $\begin{array}{l}\text { Langmuir and } \\
\text { Freundlich }\end{array}$ & Pseudo-first order & $8.06 \mathrm{mg} / \mathrm{g}$ & $47.0-78.7$ & \\
\hline & $\mathrm{CR}$ & Langmuir & Pseudo-second order & $6.72 \mathrm{mg} / \mathrm{g}$ & $30.5-66.5$ & \\
\hline Coconut coir & MB & Langmuir and Temkin & Pseudo-second order & $29.5 \mathrm{mg} / \mathrm{g}$ & 99.5 & [72] \\
\hline Corn cob & $\begin{array}{l}\mathrm{Mn}(\mathrm{II}) \\
\mathrm{Cu}(\mathrm{II}) \\
\mathrm{Cu} \\
\mathrm{Cd} \\
\mathrm{Ni} \\
\mathrm{Pb} \\
\end{array}$ & $\begin{array}{c}\text { Langmuir } \\
\text { Langmuir } \\
\text { N.R } \\
\text { N.R } \\
\text { N.R } \\
\text { N.R } \\
\end{array}$ & $\begin{array}{l}\text { Pseudo-second order } \\
\text { Pseudo-second order } \\
\text { N.R } \\
\text { N.R } \\
\text { N.R } \\
\text { N.R }\end{array}$ & $\begin{array}{c}6.24 \mathrm{mg} / \mathrm{g} \\
6.24 \mathrm{mg} / \mathrm{g} \\
0.034 \mathrm{mmol} / \mathrm{g} \\
0.096 \mathrm{mmol} / \mathrm{g} \\
0.097 \mathrm{mmol} / \mathrm{g} \\
0.019 \mathrm{mmol} / \mathrm{g} \\
\end{array}$ & $\begin{array}{l}99.8 \\
99.7 \\
22 \\
58 \\
60 \\
12\end{array}$ & {$[73,104]$} \\
\hline $\begin{array}{c}\text { Durian peel } \\
\text { (HCl-treated) }\end{array}$ & AG25 & Langmuir & Pseudo-second order & $63.29 \mathrm{mg} / \mathrm{g}$ & N.R & [74] \\
\hline Grapefruit peel & $\mathrm{CV}$ & Langmuir & Pseudo-second order & $254.16 \mathrm{mg} / \mathrm{g}$ & 96 & [75] \\
\hline Jackfruit peel & MB & Type 2 Langmuir & Pseudo-second order & $285.71 \mathrm{mg} / \mathrm{g}$ & $58.2-89.8$ & [76] \\
\hline $\begin{array}{c}\text { Kiwi peel } \\
\text { (NaOH-treated) }\end{array}$ & $\begin{array}{l}\mathrm{Cd}(\mathrm{II}) \\
\mathrm{Cr}(\mathrm{III}) \\
\mathrm{Zn}(\mathrm{II})\end{array}$ & $\begin{array}{l}\text { Langmuir } \\
\text { Langmuir } \\
\text { Langmuir }\end{array}$ & $\begin{array}{l}\text { Pseudo-second order } \\
\text { Pseudo-second order } \\
\text { Pseudo-second order }\end{array}$ & $\begin{array}{l}15.87 \mathrm{mg} / \mathrm{g} \\
41.66 \mathrm{mg} / \mathrm{g} \\
37.03 \mathrm{mg} / \mathrm{g}\end{array}$ & $\begin{array}{l}78 \\
98 \\
57 \\
\end{array}$ & {$[77,94]$} \\
\hline Mango Peel & $\begin{array}{l}\mathrm{Cd}(\mathrm{II}) \\
\mathrm{Pb}(\mathrm{II})\end{array}$ & $\begin{array}{l}\text { Langmuir } \\
\text { Langmuir }\end{array}$ & $\begin{array}{l}\text { Pseudo-second order } \\
\text { Pseudo-second order }\end{array}$ & $\begin{array}{l}68.92 \mathrm{mg} / \mathrm{g} \\
99.05 \mathrm{mg} / \mathrm{g}\end{array}$ & $\begin{array}{l}90.56 \\
92.5\end{array}$ & {$[10,78]$} \\
\hline $\begin{array}{c}\text { Mangosteen } \\
\text { pericarps (ABR) }\end{array}$ & Iodide $\left(\mathrm{I}^{-}\right)$ & Langmuir & Pseudo-second order & $79.4 \mathrm{mg} / \mathrm{g}$ & 100 & [79] \\
\hline $\begin{array}{c}\text { Olive waste } \\
\left(\mathrm{H}_{3} \mathrm{PO}_{4} \text {-activated }\right)\end{array}$ & $\begin{array}{l}\text { IBU } \\
\text { NPX } \\
\text { KTP } \\
\text { DCF }\end{array}$ & $\begin{array}{l}\text { Langmuir } \\
\text { Langmuir } \\
\text { Langmuir } \\
\text { Langmuir }\end{array}$ & $\begin{array}{l}\text { Pseudo-second order } \\
\text { Pseudo-second order } \\
\text { Pseudo-second order } \\
\text { Pseudo-second order }\end{array}$ & $\begin{array}{l}12.6 \mathrm{mg} / \mathrm{g} \\
39.5 \mathrm{mg} / \mathrm{g} \\
24.7 \mathrm{mg} / \mathrm{g} \\
56.2 \mathrm{mg} / \mathrm{g}\end{array}$ & $\begin{array}{l}79 \\
95 \\
90 \\
96\end{array}$ & [105] \\
\hline \multirow{4}{*}{ Orange peel } & V-17 & $\begin{array}{l}\text { Langmuir and } \\
\text { Freundlich } \\
\text { Langmuir and } \\
\text { Freundlich }\end{array}$ & Pseudo-first order & $22.44 \mathrm{mg} / \mathrm{g}$ & 76.6 & \multirow{4}{*}{$\begin{array}{c}{[10,80,81} \\
95]\end{array}$} \\
\hline & $\mathrm{PO}$ & $\begin{array}{l}\text { Langmuir and } \\
\text { Freundlich }\end{array}$ & Pseudo-first order & $1.3 \mathrm{mg} / \mathrm{g}$ & 49 & \\
\hline & $\mathrm{RB}$ & $\begin{array}{l}\text { Langmuir and } \\
\text { Freundlich }\end{array}$ & Pseudo-first order & $3.23 \mathrm{mg} / \mathrm{g}$ & $59.0-67.5$ & \\
\hline & $\begin{array}{l}\text { DR23 } \\
\text { DR80 }\end{array}$ & $\begin{array}{l}\text { Langmuir } \\
\text { Langmuir }\end{array}$ & $\begin{array}{l}\text { Pseudo-second order } \\
\text { Pseudo-second order }\end{array}$ & $\begin{array}{l}10.72 \mathrm{mg} / \mathrm{g} \\
21.05 \mathrm{mg} / \mathrm{g}\end{array}$ & $\begin{array}{l}92 \\
91\end{array}$ & \\
\hline $\begin{array}{c}\text { Papaya Peel } \\
\left(\mathrm{H}_{3} \mathrm{PO}_{4} \text {-activated }\right) \\
\end{array}$ & $\mathrm{Pb}(\mathrm{II})$ & Langmuir & Pseudo-second order & $38.31 \mathrm{mg} / \mathrm{g}$ & 93.22 & [39] \\
\hline $\begin{array}{l}\text { Passion fruit } \\
\text { rinds (ABR) }\end{array}$ & Iodide $\left(\mathrm{I}^{-}\right)$ & Langmuir & Pseudo-second order & $6.67 \mathrm{mg} / \mathrm{g}$ & 87.5 & [79] \\
\hline $\begin{array}{c}\text { Peach stones } \\
\left(\mathrm{K}_{2} \mathrm{CO}_{3} \text {-activated }\right) \\
\end{array}$ & ACE & Langmuir & Pseudo-second order & $204 \mathrm{mg} / \mathrm{g}$ & 82 & [54] \\
\hline
\end{tabular}


Table 4. Cont.

\begin{tabular}{|c|c|c|c|c|c|c|}
\hline Biowaste & Contaminant & $\begin{array}{c}\text { Isothermal } \\
\text { Model Adjusted }\end{array}$ & $\begin{array}{c}\text { Kinetic } \\
\text { Model Adjusted }\end{array}$ & $\mathbf{q}_{\mathrm{m}} / \mathbf{Q}^{\circ}$ & $\begin{array}{c}\text { Removal } \\
\text { Efficiency (\%) }\end{array}$ & Ref. \\
\hline $\begin{array}{l}\text { Pineapple waste } \\
\left(\mathrm{ZnCl}_{2} \text {-activated) }\right.\end{array}$ & MB & Langmuir & N.R & $288.34 \mathrm{mg} / \mathrm{g}$ & $67-76$ & [48] \\
\hline Pomegranate peel & $\mathrm{Cu}(\mathrm{II})$ & $\begin{array}{l}\text { Langmuir, } \\
\text { Freundlich, Dubinin } \\
\text { Radushkevich } \\
\text { and Temkin }\end{array}$ & Pseudo-second order & $30.12 \mathrm{mg} / \mathrm{g}$ & 78.85 & [103] \\
\hline \multirow{2}{*}{ Pomelo peel } & $\mathrm{MB}$ & \multirow{2}{*}{$\begin{array}{l}\text { Langmuir } \\
\text { and Temkin } \\
\text { Langmuir }\end{array}$} & Pseudo-second order & $133 \mathrm{mg} / \mathrm{g}$ & 83 & \multirow{2}{*}{$1,83,96$} \\
\hline & RB-114 & & Pseudo-second order & $16.3 \mathrm{mg} / \mathrm{g}$ & 89 & \\
\hline $\begin{array}{l}\text { Red dragon fruit } \\
\text { peels (ABR) }\end{array}$ & Iodide $\left(\mathrm{I}^{-}\right)$ & Freundlich & Pseudo-second order & $68.6 \mathrm{mg} / \mathrm{g}$ & 68.4 & [79] \\
\hline $\begin{array}{l}\text { Red onion peels } \\
\text { (ABR) }\end{array}$ & Iodide $\left(\mathrm{I}^{-}\right)$ & Langmuir & Pseudo-second order & $75.8 \mathrm{mg} / \mathrm{g}$ & 92 & [79] \\
\hline $\begin{array}{l}\text { Rice husk and fruit } \\
\text { juice residue }\end{array}$ & Phosphate & Freundlich & Pseudo-first order & $13.89 \mathrm{mg} / \mathrm{g}$ & 95.85 & [49] \\
\hline \multirow{3}{*}{$\begin{array}{l}\text { Tangerine peel } \\
\text { (NaOH-treated) }\end{array}$} & $\mathrm{Cd}(\mathrm{II})$ & Langmuir & Pseudo-second order & $17.54 \mathrm{mg} / \mathrm{g}$ & 73 & \multirow{3}{*}[77,94]{} \\
\hline & $\mathrm{Cr}(\mathrm{III})$ & Langmuir & Pseudo-second order & $47.61 \mathrm{mg} / \mathrm{g}$ & 96 & \\
\hline & $\mathrm{Zn}(\mathrm{II})$ & Langmuir & Pseudo-second order & $38.41 \mathrm{mg} / \mathrm{g}$ & 52 & \\
\hline \multirow{18}{*}{ Watermelon rinds } & $\mathrm{Cu}(\mathrm{II})$ & Langmuir & Pseudo-second order & $5.7-111.1 \mathrm{mg} / \mathrm{g}$ & $58.4-88$ & \multirow{18}{*}{ [3] } \\
\hline & $\mathrm{Ni}(\mathrm{II})$ & N.R & N.R & $18.4-38.9 \mathrm{mg} / \mathrm{g}$ & $69-70$ & \\
\hline & $\mathrm{Zn}(\mathrm{II})$ & N.R & N.R & $22.5 \mathrm{mg} / \mathrm{g}$ & $52.4-90.3$ & \\
\hline & $\mathrm{Pb}(\mathrm{II})$ & $\begin{array}{l}\text { Langmuir, Thomas } \\
\text { and Yoon-Nelson }\end{array}$ & Pseudo-second order & $19.33-116.2 \mathrm{mg} / \mathrm{g}$ & 72-99.9 & \\
\hline & $\mathrm{Cd}(\mathrm{II})$ & Langmuir & Pseudo-second order & $40.16-63.29 \mathrm{mg} / \mathrm{g}$ & 80 & \\
\hline & $\mathrm{Cr}(\mathrm{III})$ & Langmuir & Pseudo-second order & $172.6 \mathrm{mg} / \mathrm{g}$ & 91 & \\
\hline & $\mathrm{Tl}(\mathrm{I})$ & $\begin{array}{l}\text { Langmuir and } \\
\text { Temkin }\end{array}$ & Pseudo-second order & $178.4-1123 \mathrm{mg} / \mathrm{g}$ & $98-98.5$ & \\
\hline & As(III) & Langmuir & Pseudo-second order & NR & 99 & \\
\hline & As(V) & Langmuir & Pseudo-second order & NR & 98 & \\
\hline & $\mathrm{Fe}(\mathrm{II})$ & N.R & N.R & $4.98 \mathrm{mg} / \mathrm{g}$ & 98.3 & \\
\hline & Mn(II) & N.R & N.R & $1.37 \mathrm{mg} / \mathrm{g}$ & 98.9 & \\
\hline & $\mathrm{Co}(\mathrm{II})$ & N.R & N.R & $23.3 \mathrm{mg} / \mathrm{g}$ & 57 & \\
\hline & $\mathrm{MB}$ & Langmuir & Pseudo-second order & $188.6-489.8 \mathrm{mg} / \mathrm{g}$ & $83-99$ & \\
\hline & BG & Langmuir & Pseudo-second order & $188.6 \mathrm{mg} / \mathrm{g}$ & 98 & \\
\hline & RBBR & Freundlich & Pseudo-second order & $333.33 \mathrm{mg} / \mathrm{g}$ & $92-97$ & \\
\hline & CR & Langmuir & Pseudo-second order & $17 \mathrm{mg} / \mathrm{g}$ & 101.45 & \\
\hline & BR2 & Extended Langmuir & Pseudo-first order & $125.79 \mathrm{mg} / \mathrm{g}$ & 75 & \\
\hline & OG & Extended Langmuir & Pseudo-first order & $27.24 \mathrm{mg} / \mathrm{g}$ & 85 & \\
\hline
\end{tabular}

N.R, not reported; IBU, Ibuprofen; MO, Methyl orange; MB, Methylene blue; RB, Rhodamine B; CR, Congo red MV, Methyl violet; AB-10B, Amido black 10B; AV, Acid violet; AG25, Acid green 25; CV, Crystal violet; NPX Naproxen; KTP, Ketoprofen; DCF, Diclofenac; V-17, Violet 17; PO, Procion orange; DR23, Direct Red 23; DR80, Direct red 80; ACE, Acetaminophen; RB-114; Reactive blue 114; BG, Brilliant green; RBBR, Remazol brilliant blue reactive; BR2, Basic red 2; OG, Orange G; ABR, Anthocyanin based residues.

$\mathrm{Cr}(\mathrm{III})$ and $\mathrm{Pb}(\mathrm{II})$ are other metals that commonly appear in water matrix analyses. $\mathrm{Cr}(\mathrm{III})$ was removed by watermelon rinds and coconut residues with an efficiency and maximum adsorption capacity up to $98.2 \%$ and $172.6 \mathrm{mg} / \mathrm{g}$, respectively, under acidic conditions $(\mathrm{pH} 3)[3,59]$. Kiwi and tangerine peels exhibited notable adsorbing efficiencies (98\% and 96\% respectively) for $\mathrm{Cr}(\mathrm{III})$, reaching equilibrium in $60 \mathrm{~min}$ at $\mathrm{pH} 6.0$ [77,94]. As for $\mathrm{Cr}(\mathrm{VI})$, banana peels adsorbed it following the Langmuir isotherm with a $\mathrm{q}_{\mathrm{m}}$ of $131.56 \mathrm{mg} / \mathrm{g}$ after $30 \mathrm{~min}$ of contact time [61]. Watermelon rinds sequestered $\mathrm{Pb}(\mathrm{II})$, reaching removal percentages between $72 \%$ and $99.9 \%$ within a temperature range of $20-30{ }^{\circ} \mathrm{C}$ [3] When an acidic and alkaline treatment was carried out on the watermelon rinds it was possible to capture from 52.4 to $90.3 \%$ of $\mathrm{Zn}$ (II); although the lowest removal percentages were observed in the presence of other metals in solution, this demonstrated that the simultaneous bioadsorption of multiple pollutants is possible. Similarly, tangerine and kiwi peels achieved a $\mathrm{Zn}$ (II) adsorption efficiency of approximately $52 \%$ and $57 \%$, respectively, at $\mathrm{pH} 6.0$, respective with $\mathrm{q}_{\mathrm{m}}$ values of 38.4 and $37.0 \mathrm{mg} / \mathrm{g}$ [77]. After identifying the optimal adsorption conditions, papaya peels displayed a removal efficiency of $93.2 \%$ for $\mathrm{Pb}(\mathrm{II})$, and according to the Langmuir and kinetic models the adsorptive capacity ranged from 38.31 to $42.5 \mathrm{mg} / \mathrm{g}$ [39]. Another fruit peel that presented good removal efficiency 
of lead after chemical modification was mango peel waste, retaining $76.2 \%$ of this metal rapidly (30-60 $\mathrm{min}$ ) with a $\mathrm{q}_{\mathrm{m}}$ of $99.05 \mathrm{mg} / \mathrm{g}$ based on the Langmuir isotherm model [10].

Many fruit residues have been reported to have a certain affinity for other heavy metals that may represent a hazard for human beings. The ability of watermelon rinds, mango peel waste, and banana, kiwi, and tangerine peel residues to retain $\mathrm{Cd}(\mathrm{II})$ from water sources was studied; the respective removal efficiencies obtained were $80 \%, 90.5 \%$, $95 \%, 78 \%$, and $73 \%[3,10,60,61,94]$. The Langmuir isotherm and pseudo-first and secondorder kinetic models were best suited for describing $\mathrm{Cd}$ uptake by these biomaterials. Šćiban, et al. [73] reported similar adsorption capacities for cadmium and nickel (0.096 and $0.097 \mathrm{mmol} / \mathrm{g}$ respectively) using raw corn cob as biosorbent, while coconut waste presented a maximum $\mathrm{Ni}(\mathrm{II})$ adsorption of $15.95 \mathrm{mg} / \mathrm{g}$ at $\mathrm{pH} 5.3$ [59]. Raw corn cob was studied by Kumar et al. [104] for the almost complete reduction of Mn(II) (99.8\%) in industrial wastewater after $60 \mathrm{~min}$ at $\mathrm{pH} 5.0$ and $40^{\circ} \mathrm{C}$. The maximum adsorption capacity was $6.24 \mathrm{mg} / \mathrm{g}$ following the pseudo-second order kinetics. This removal efficiency was the highest when compared to that obtained with watermelon rinds $(98.9 \%)$ or beet pulp $(86.3 \%)$ at an adsorbent concentration of $1 \mathrm{~g} / \mathrm{L}$ and $\mathrm{pH} 6[3,88]$.

Coconut waste represented an adequate option for the removal of $\mathrm{Co}$ (II) from water, showing a maximum adsorption capacity of $12.82 \mathrm{mg} / \mathrm{g}$ at $\mathrm{pH} 4.3$ [59]. The kinetic and equilibrium parameters were well-explained by the Langmuir model, which demonstrated the presence of stable chemical bonds between the molecules across the surface area. Recently, Bhattacharjee et al. [3] used watermelon rinds as an adsorbent material in water sources and reported removal efficiencies for Co(II) (57\%), Tl(I) (98-98.5\%), As(III) (99\%), $\mathrm{As}(\mathrm{V})(98 \%), \mathrm{Ni}(\mathrm{II})(69-70 \%)$, and $\mathrm{Fe}(\mathrm{II})(98.3 \%)$.

\subsubsection{Industrial Contaminants}

Removing dyes from aqueous solutions can be a difficult task with conventional treatment methods. However, the bioadsorbent application of fruit biowastes as AC or raw material has been studied for dye removal (Table 4). For instance, watermelon rind-based AC adsorbed brilliant green, remazol brilliant blue reactive, basic red 2, and orange $\mathrm{G}$, showing removal efficiencies of $98,94.5 \pm 2.5,75$ and $85 \%$, respectively, at $30{ }^{\circ} \mathrm{C}$ and $\mathrm{q}_{\mathrm{m}}$ values in the range of $27.4-333.3 \mathrm{mg} / \mathrm{g}$ [3]. It is important to mention that the dye adsorption was both endothermic (remazol brilliant blue reactive and basic red 2) and exothermic (brilliant green and orange $\mathrm{G}$ ). In the same study a dominance of ion-exchange sorption towards MB was present, with maximum capacity values of $188.6-489.8 \mathrm{mg} / \mathrm{g}$ and removal efficiencies from $83 \%$ to $98 \%$. The models that best described the kinetic and equilibrium data were pseudo-second order and Langmuir isotherm. Additionally, coconut coir powder without chemical treatment exhibited a monolayer adsorption capacity of $29.50 \mathrm{mg} / \mathrm{g}$ for $\mathrm{MB}$ under optimal conditions $\left(30^{\circ} \mathrm{C}\right.$ and $\mathrm{pH}$ 6.0), achieving maximum removal efficiency when the adsorbent dosage increased from 0.05 to $0.20 \mathrm{~g}$ [72]. In this case, the authors determined that the Temkin isotherm model was adequate to describe the adsorption behavior, as it considers that the adsorption heat of the molecules decreases linearly along the surface by adsorbent-adsorbate interactions. Depending on the initial adsorbent concentration, after 180 min of contact time the removal efficiency for MB using jackfruit peels without pre-treatment varied from 58.2 to $89.8 \%$ with a maximum adsorption capacity of $285.71 \mathrm{mg} / \mathrm{g}$ [74]. AC from pineapple waste was identified as another efficient bioadsorbent for MB recovery, presenting an outstanding adsorption capacity $(288.34 \mathrm{mg} / \mathrm{g})$ and removal efficiencies from 67 to $76 \%$, according to the Langmuir isotherm [48]. Other biowastes of interest include pomelo and banana peels; the former exhibited a maximum MB removal efficiency of $83 \%$ with a $\mathrm{q}_{\mathrm{m}}$ of $133 \mathrm{mg} / \mathrm{g}$, while the latter reached a maximum adsorption capacity of $15.9 \mathrm{mg} / \mathrm{g}$ at the same temperature $\left(30^{\circ} \mathrm{C}\right)$ and different $\mathrm{pH}(8$ and 6 , respectively) $[67,96]$. Pomelo peels without any chemical treatment were studied by Argun et al. [83], retaining antraquinonic dye reactive blue 114 from aqueous solutions; adsorption reached equilibrium $(16.3 \mathrm{mg} / \mathrm{g})$ within a $90 \mathrm{~min}$ reaction time, with a maximum removal efficiency of $96 \%$. 
Congo red is another widely-used dye with carcinogenic properties that needs to be monitored and removed from water sources. Bhattacharjee et al. [3] reported that AC from watermelon rinds adsorbed it at a capacity of up to $17 \mathrm{mg} / \mathrm{g}$, with efficiency above $100 \%$ when using sonication and modification with $\mathrm{TiO}_{2}$ nanoparticles. When the adsorption was assisted by the ultrasound method, the acoustic waves caused the water to create gas bubbles or cavities, increasing the surface area and facilitating contact between the dye and the biosorbent [106]. Coir pith presented notable removal percentages of congo red under acidic conditions, varying from 30.5 to $66.5 \%$ depending on the dye concentration [46]. This bioresidue is interesting for violet acid recovery, because after thermal treatment it exhibited up to $78.7 \%$ dye removal and attained equilibrium after the first $10 \mathrm{~min}$ of adsorption [46]. Congo red was removed using orange peel with a maximum removal efficiency reaching up to $76.6 \%$ at $\mathrm{pH} 5$ and decaying to $49 \%$ at $\mathrm{pH} 12$ [80]. Banana peel was evaluated for the adsorption of congo red, methyl orange, methyl violet, and amido black $10 \mathrm{~B}$ at initial concentrations of $100 \mathrm{mg} / \mathrm{g}$, achieving maximum adsorption capacities of $11.2,17.2$, and $7.9 \mathrm{mg} / \mathrm{g}$, respectively [67]. The Langmuir and Freundlich isotherms were used to describe the adsorption behaviors, with the latter a better fit for the data.

Orange peels were tested as an effective bioadsorbent ( $87 \%$ removal) for violet 17 at $\mathrm{pH} 2$ and showed the ability to recover more than $60 \%$ of the adsorbate with increasing $\mathrm{pH}$ [95]. Procion orange, direct red 23, and direct red 80 were effectively adsorbed by non-treated orange peels with a maximum removal efficiency of $49 \%$ [80], $92 \%$, and $91 \%$ respectively, at initial dye concentrations of $50 \mathrm{mg} / \mathrm{L}$ [81]. Langmuir showed a better fit in most cases, indicating monolayer adsorption [10]. Rhodamine-B was adsorbed by orange peels as well, displaying a removal efficiency and $\mathrm{q}_{\mathrm{m}}$ of $63.5 \%$ and $3.2 \mathrm{mg} / \mathrm{g}$, respectively, while calcined coir pith wastes removed $43.6-79.4 \%$ of this dye [47]. Additionally, a maximum adsorption capacity of $13.2 \mathrm{mg} / \mathrm{g}$ for rhodamine-B was achieved with banana peels at $\mathrm{pH} 7$, following a Freundlich adsorption behavior [67].

Grapefruit peels were an excellent adsorbent for crystal violet, with higher desorption efficiency $(\leq 98 \%)$ after several cycles of regeneration with $\mathrm{NaOH}$. Sorption equilibrium was reached within $60 \mathrm{~min}$, resulting in $96 \%$ removal of the dye [75]. Durian peels showed an important adsorption capacity of $63.2 \mathrm{mg} / \mathrm{g}$ for acid green 25 at $30^{\circ} \mathrm{C}$; the good adjustment of the Langmuir model indicated that this biomaterial had equal adsorption activation energy for each dye molecule [74].

\subsubsection{Nutrients}

Nutrients such as phosphate ions have been successfully recovered from aqueous solutions using an adsorbent derived from rice husk and lemon juice residues [49]. It displayed a removal efficiency of $95.8 \%$ at $298 \mathrm{~K}$ and $\mathrm{pH} 6$; the initial adsorbate concentration, adsorbent dose (5 and $3 \mathrm{~g} / \mathrm{L}$ respectively), and contact time (three hours) were important to achieve the highest efficiency in the process. Banana peels were used as an environmentally friendly option for uptake of fluoride from groundwater, reaching a removal efficiency of $86.5 \%\left(\mathrm{q}_{\mathrm{m}}=8.15 \mathrm{mg} / \mathrm{g}\right)$ under optimal conditions for the sorbent [68]. Anthocyanin-based bioadsorbents were subsequently implemented to remove ions of radioactive iodine $\left(\mathrm{I}^{-}\right)$ from an aqueous environment. Mangosteen pericarps were the most efficient adsorbent, showing total removal of iodine $(100 \%)$, followed by red onion peels $(92 \%)$, passion fruit rinds $(87.5 \%)$, and red dragon fruit peels (68.4\%) after a contact period of $192 \mathrm{~h}$ [79]. The Freundlich, Langmuir, and pseudo-first and second order were the isothermal and kinetic models employed for the analysis of nutrients adsorption data (Table 4).

\subsubsection{Pharmaceuticals}

Chakraborty et al. [53], among others (Table 4), evaluated fruit residues for the removal of common non-prescription drugs from water. AC from Aegle marmelos shells was subjected to steaming activation, achieving the highest removal efficiency of $95 \%$ for ibuprofen, while its raw form reached $90 \%$ under different $\mathrm{pH}$ and temperature conditions $\left(15{ }^{\circ} \mathrm{C}\right.$ and $\mathrm{pH} 3$ vs. $20^{\circ} \mathrm{C}$ and $\mathrm{pH} 2$, respectively). In addition, $\mathrm{AC}$ produced from olive waste 
cakes followed the pseudo-second order kinetic model and Langmuir isotherm for the adsorption of ibuprofen, ketoprofen, naproxen, and diclofenac from surface water samples. The maximum removal of the four drugs was observed at $\mathrm{pH} 2.01$, although this decreased to $90.4,88.4$, and $70.0 \%$ for naproxen, ketoprofen, and ibuprofen, respectively, when they were mixed in solution at $25^{\circ} \mathrm{C}$ [105]. AC derived from peach stones was proposed by Cabrita et al. [54] for the adsorption of the analgesic acetaminophen from water, with an efficiency of $82 \%$ and $\mathrm{qm}_{\mathrm{m}}$ of $204 \mathrm{mg} / \mathrm{g}$ at $30{ }^{\circ} \mathrm{C}$ while using only $10 \mathrm{mg}$ of the adsorbent.

\subsection{Bioadsorbents Based on Herbage and Forage}

\subsubsection{Heavy Metals}

Heavy metals have been removed from aqueous environments using adsorbents obtained from herbs and forage (Table 5). Ahmed et al. [88] investigated the potential of SCB for treating Mn(II) present in ground water, considering as optimum conditions an adsorbent dosage of $1.5 \mathrm{~g}$ and an initial heavy metal concentration of $2 \mathrm{mg} / \mathrm{L}$ at $\mathrm{pH} 6 . \mathrm{Mn}$ (II) was successfully removed with an efficiency of $62.5 \%$, explained under a pseudo-second order kinetic model. Using a ten-fold quantity of raw SCB, it was possible to eliminate a higher concentration of this metal $(12 \mathrm{mg} / \mathrm{L})$ with similar efficiency [87]. Additional chemical pretreatment with hydrochloric acid had a significant positive effect on this adsorbent, increasing the removal to $99 \%$ due to the increase of carboxyl and hydroxyl groups on its surface. Tea and sunflower wastes were implemented for Mn(II) uptake, obtaining removal efficiencies of 95.5 and $81.6 \%$, respectively, at pH 8 [89,92]. Particularly, the sunflower residue presented a higher maximum adsorption capacity $(47.6 \mathrm{mg} / \mathrm{g})$ than tea waste $(0.15 \mathrm{mg} / \mathrm{g})$; the Langmuir isotherm model was employed.

Table 5. Adsorption parameters and removal efficiencies of different biosorbents derived from herbage and forage for the removal of pollutants in aqueous matrices.

\begin{tabular}{|c|c|c|c|c|c|c|}
\hline Biowaste & Contaminant & $\begin{array}{c}\text { Isothermal Model } \\
\text { Adjusted }\end{array}$ & $\begin{array}{l}\text { Kinetic Model } \\
\text { Adjusted }\end{array}$ & $\mathrm{q}_{\mathrm{m}} / \mathrm{Q}_{\mathrm{e}}$ & $\begin{array}{c}\text { Removal } \\
\text { Efficiency (\%) }\end{array}$ & Ref. \\
\hline \multirow{4}{*}{ Barley straw } & BBY & Langmuir & Pseudo-second order & $124.3 \mathrm{mg} / \mathrm{g}$ & N.R & \multirow{4}{*}{ [69] } \\
\hline & $\mathrm{CV}$ & Langmuir & Pseudo-second order & $95.8 \mathrm{mg} / \mathrm{g}$ & N.R & \\
\hline & MB & Langmuir & Pseudo-second order & $86.5 \mathrm{mg} / \mathrm{g}$ & N.R & \\
\hline & $\mathrm{SO}$ & Langmuir & Pseudo-second order & $99.7 \mathrm{mg} / \mathrm{g}$ & N.R & \\
\hline \multirow{4}{*}{$\begin{array}{c}\text { Barley straw } \\
\text { (CA/NaOH-modified) }\end{array}$} & BBY & Langmuir & Pseudo-second order & $524.3 \mathrm{mg} / \mathrm{g}$ & N.R & \multirow{4}{*}[69]{} \\
\hline & $\mathrm{CV}$ & Langmuir & Pseudo-second order & $473.2 \mathrm{mg} / \mathrm{g}$ & N.R & \\
\hline & MB & Langmuir & Pseudo-second order & $498.1 \mathrm{mg} / \mathrm{g}$ & N.R & \\
\hline & $\mathrm{SO}$ & Langmuir & Pseudo-second order & $296.6 \mathrm{mg} / \mathrm{g}$ & N.R & \\
\hline \multirow{4}{*}{ Barley straw (Magnetic) } & BBY & Langmuir & Pseudo-second order & $137.6 \mathrm{mg} / \mathrm{g}$ & N.R & \multirow{4}{*}{ [69] } \\
\hline & $\mathrm{CV}$ & Langmuir & Pseudo-second order & $96.1 \mathrm{mg} / \mathrm{g}$ & N.R & \\
\hline & MB & Langmuir & Pseudo-second order & $94.1 \mathrm{mg} / \mathrm{g}$ & N.R & \\
\hline & $\mathrm{SO}$ & Langmuir & Pseudo-second order & $102 \mathrm{mg} / \mathrm{g}$ & N.R & \\
\hline \multirow{4}{*}{$\begin{array}{l}\text { Barley straw (Magnetic } \\
\mathrm{CA} / \mathrm{NaOH} \text {-modified) }\end{array}$} & BBY & Langmuir & Pseudo-second order & $520.3 \mathrm{mg} / \mathrm{g}$ & N.R & \multirow{4}{*}[69]{} \\
\hline & $\mathrm{CV}$ & Langmuir & Pseudo-second order & $410.8 \mathrm{mg} / \mathrm{g}$ & N.R & \\
\hline & MB & Langmuir & Pseudo-second order & $455.8 \mathrm{mg} / \mathrm{g}$ & N.R & \\
\hline & $\mathrm{SO}$ & Langmuir & Pseudo-second order & $460.7 \mathrm{mg} / \mathrm{g}$ & N.R & \\
\hline \multirow{2}{*}{ Black tea } & $\mathrm{Cu}$ & Langmuir & Pseudo-second order & $48 \mathrm{mg} / \mathrm{g}$ & 77 & \multirow{2}{*}{ [90] } \\
\hline & $\mathrm{Pb}$ & Freundlich & Pseudo-second order & $65 \mathrm{mg} / \mathrm{g}$ & 94 & \\
\hline Cauliflower leaf powder & MB & Freundlich & Pseudo-second order & $149.22 \mathrm{mg} / \mathrm{g}$ & 88.1 & {$[70]$} \\
\hline \multirow{4}{*}{ Corn stalks } & $\mathrm{Cu}$ & N.R & N.R & $0.059 \mathrm{mmol} / \mathrm{g}$ & 35 & \multirow{4}{*}{ [73] } \\
\hline & $\mathrm{Cd}$ & N.R & N.R & $0.046 \mathrm{mmol} / \mathrm{g}$ & 30 & \\
\hline & $\mathrm{Ni}$ & N.R & N.R & $0.009 \mathrm{mmol} / \mathrm{g}$ & 8 & \\
\hline & $\mathrm{Pb}$ & N.R & N.R & $0.029 \mathrm{mmol} / \mathrm{g}$ & 20 & \\
\hline $\begin{array}{l}\text { Date palm wastes } \\
\text { (Surface fibres) }\end{array}$ & Phosphates & N.R & N.R & N.R & 85 & [107] \\
\hline $\begin{array}{l}\text { Date palm wastes } \\
\text { (Date stones) }\end{array}$ & Phosphates & N.R & N.R & N.R & 87 & [107] \\
\hline $\begin{array}{c}\text { Date palm tree leaves } \\
\left(\mathrm{H}_{2} \mathrm{SO}_{4} \text {-activated }\right)\end{array}$ & $\mathrm{Pb}$ & Langmuir & Pseudo-second order & $88.61 \mathrm{mg} / \mathrm{g}$ & 98.6 & {$[41]$} \\
\hline Mixed tea waste & $\mathrm{Cr}(\mathrm{VI})$ & Freundlich & Pseudo-second order & $94.34 \mathrm{mg} / \mathrm{g}$ & $\sim 97$ & [93] \\
\hline
\end{tabular}


Table 5. Cont.

\begin{tabular}{|c|c|c|c|c|c|c|}
\hline Biowaste & Contaminant & $\begin{array}{c}\text { Isothermal Model } \\
\text { Adjusted }\end{array}$ & $\begin{array}{l}\text { Kinetic Model } \\
\text { Adjusted }\end{array}$ & $\mathrm{q}_{\mathrm{m}} / \mathrm{Q}_{\mathrm{e}}$ & $\begin{array}{c}\text { Removal } \\
\text { Efficiency (\%) }\end{array}$ & Ref. \\
\hline \multirow{2}{*}{ Potato Stem powder } & MB & $\begin{array}{l}\text { Langmuir and } \\
\text { Freundlich }\end{array}$ & Pseudo-second order & $41.6 \mathrm{mg} / \mathrm{g}$ & 82 & \multirow[t]{2}{*}{ [84] } \\
\hline & MG & $\begin{array}{l}\text { Langmuir and } \\
\text { Freundlich }\end{array}$ & Pseudo-second order & $27.0 \mathrm{mg} / \mathrm{g}$ & 67 & \\
\hline \multirow[t]{2}{*}{ Potato Leaves powder } & MB & $\begin{array}{l}\text { Langmuir and } \\
\text { Freundlich }\end{array}$ & Pseudo-second order & $52.6 \mathrm{mg} / \mathrm{g}$ & 87 & \multirow[t]{2}{*}[84]{} \\
\hline & MG & $\begin{array}{l}\text { Langmuir and } \\
\text { Freundlich }\end{array}$ & Pseudo-second order & $33.3 \mathrm{mg} / \mathrm{g}$ & 75 & \\
\hline \multirow{4}{*}{ Raw wheat straw } & $\mathrm{Cu}$ & N.R & N.R & $0.070 \mathrm{mmol} / \mathrm{g}$ & 42 & \multirow{4}{*}[73]{} \\
\hline & $\mathrm{Cd}$ & N.R & N.R & $0.089 \mathrm{mmol} / \mathrm{g}$ & 55 & \\
\hline & $\mathrm{Ni}$ & N.R & N.R & $0.051 \mathrm{mmol} / \mathrm{g}$ & 30 & \\
\hline & $\mathrm{Pb}$ & N.R & N.R & $0.015 \mathrm{mmol} / \mathrm{g}$ & 10 & \\
\hline \multirow{3}{*}{ Rice straw } & $\mathrm{Pb}(\mathrm{II})$ & Langmuir & N.R & $42.55 \mathrm{mg} / \mathrm{g}$ & 94 & \multirow{3}{*}[16,85]{} \\
\hline & CA & Freundlich & Pseudo-second order & $126.3 \mathrm{mg} / \mathrm{g}$ & 42.5 & \\
\hline & CBZ & Freundlich & Pseudo-second order & $40.0 \mathrm{mg} / \mathrm{g}$ & 75.3 & \\
\hline \multirow{4}{*}{ Soybean straws } & $\mathrm{Cu}$ & N.R & N.R & $0.085 \mathrm{mmol} / \mathrm{g}$ & 60 & \multirow{4}{*}[73]{} \\
\hline & $\mathrm{Cd}$ & N.R & N.R & $0.018 \mathrm{mmol} / \mathrm{g}$ & 10 & \\
\hline & $\mathrm{Ni}$ & N.R & N.R & $0.007 \mathrm{mmol} / \mathrm{g}$ & 5 & \\
\hline & $\mathrm{Pb}$ & N.R & N.R & $0.033 \mathrm{mmol} / \mathrm{g}$ & 25 & \\
\hline \multirow{2}{*}{ Sugarcane bagasse } & $\mathrm{Mn}(\mathrm{II})$ & N.R & Pseudo-second order & N.R & 62.5 & \multirow[t]{2}{*}[87,88]{} \\
\hline & $\operatorname{Mn}(\mathrm{II})$ & Langmuir & Pseudo-second order & $0.676 \mathrm{mg} / \mathrm{g}$ & 63 & \\
\hline $\begin{array}{l}\text { Sugarcane bagasse } \\
\text { (HCl-treated) }\end{array}$ & $\operatorname{Mn}(\mathrm{II})$ & Freundlich & Pseudo-second order & $1.897 \mathrm{mg} / \mathrm{g}$ & 99 & [87] \\
\hline \multirow{6}{*}{$\begin{array}{l}\text { Sugarcane bagasse } \\
\text { (NaOH-treated) }\end{array}$} & $\mathrm{Fe}(\mathrm{III})$ & Langmuir & Pseudo-second order & $331.1 \mu \mathrm{mol} / \mathrm{g}$ & $>95.0$ & \multirow{6}{*}[86]{} \\
\hline & Co(II) & N.R & N.R & $15.5 \mu \mathrm{mol} / \mathrm{g}$ & N.R & \\
\hline & $\mathrm{Cu}(\mathrm{II})$ & N.R & N.R & $86 \mu \mathrm{mol} / \mathrm{g}$ & N.R & \\
\hline & $\mathrm{Cd}(\mathrm{II})$ & N.R & N.R & $70 \mu \mathrm{mol} / \mathrm{g}$ & N.R & \\
\hline & $\mathrm{Pb}(\mathrm{II})$ & N.R & N.R & $87 \mu \mathrm{mol} / \mathrm{g}$ & N.R & \\
\hline & $\mathrm{Zn}(\mathrm{II})$ & N.R & N.R & $81 \mu \mathrm{mol} / \mathrm{g}$ & N.R & \\
\hline \multirow{3}{*}{ Sulfonated tea waste } & $\mathrm{Cr}(\mathrm{VI})$ & Langmuir & Pseudo-second order & $438.18 \mathrm{mg} / \mathrm{g}$ & 96 & \multirow{3}{*}{ [91] } \\
\hline & MB & Langmuir & Pseudo-second order & $1007.61 \mathrm{mg} / \mathrm{g}$ & $>99$ & \\
\hline & Tet & Langmuir & Pseudo-second order & $380.97 \mathrm{mg} / \mathrm{g}$ & 97 & \\
\hline \multirow{6}{*}{ Sunflower } & $\mathrm{Mn}(\mathrm{II})$ & Langmuir & Pseudo-second order & $47.6 \mathrm{mg} / \mathrm{g}$ & 81.6 & \multirow{6}{*}{ [89] } \\
\hline & $\mathrm{Cd}$ & Langmuir & Pseudo-second order & $83.3 \mathrm{mg} / \mathrm{g}$ & N.R & \\
\hline & $\mathrm{Cu}$ & Langmuir & Pseudo-second order & $30.3 \mathrm{mg} / \mathrm{g}$ & N.R & \\
\hline & $\mathrm{Zn}$ & Langmuir & Pseudo-second order & $45.4 \mathrm{mg} / \mathrm{g}$ & N.R & \\
\hline & $\mathrm{Fe}$ & Langmuir & Pseudo-second order & $71.4 \mathrm{mg} / \mathrm{g}$ & N.R & \\
\hline & $\mathrm{Ni}$ & Langmuir & Pseudo-second order & $27 \mathrm{mg} / \mathrm{g}$ & N.R & \\
\hline $\begin{array}{c}\text { Sunflower } \\
\text { (NaOH-modified) }\end{array}$ & $\mathrm{Ni}$ & Langmuir & Pseudo-second order & $41.7 \mathrm{mg} / \mathrm{g}$ & N.R & [89] \\
\hline \multirow{2}{*}{ Tea waste } & $\mathrm{Mn}(\mathrm{II})$ & Langmuir & Pseudo-second order & $0.157 \mathrm{mg} / \mathrm{g}$ & 95.5 & \multirow{2}{*}[92]{} \\
\hline & $\mathrm{Zn}(\mathrm{II})$ & Langmuir & Pseudo-second order & $0.278 \mathrm{mg} / \mathrm{g}$ & 99.5 & \\
\hline
\end{tabular}

N.R, not reported; BBY, Bismarck brown Y; CV, Crystal violet; MB, Methylene blue; SO, Safranin O; MG, Malachite green; CA, Clofibric acid; CBZ, Carbamazepine; Tet, Tetracycline; CA/NaOH, Citric acid and $\mathrm{NaOH}$.

Tea waste was evaluated as a low-cost adsorbent for the effective recovery of $\mathrm{Zn}$ (II) from synthetic wastewater, following the pseudo-second order kinetic model and reaching $99.5 \%$ removal with three grams of tea waste per $100 \mathrm{~mL}$ of metal standard solution [92]. The residues of sunflower (specifically stalks and leaves) displayed good activity as a bioadsorbent, removing $\mathrm{Zn}, \mathrm{Ni}, \mathrm{Cu}, \mathrm{Cd}$, and $\mathrm{Fe}$ from aqueous solutions. The maximum sorption capacity observed for the five metals was about $50.8 \pm 22.3 \mathrm{mg} / \mathrm{g}$ on average; the adsorption behavior for these metals was used the pseudo-second order model, showing that it is a competitive system [89]. Soliman et al. [86] employed SCB to remove Fe(III) in different water samples through the batch equilibrium technique at an optimum $\mathrm{pH}$ of 3. The average recovery efficiencies for this metal were $95-97.4 \%$ in Nile River water, $95-98.4 \%$ in groundwater, $95-98 \%$ in drinking tap water, $95 \% \pm 0.2 \%$ in natural drinking water, and $97.2-98.2 \%$ in distilled water. The adsorption reaction was adjusted to $\mathrm{pH} 5$ for the maximum uptake of $\mathrm{Co}(\mathrm{II})(15.5 \mu \mathrm{mol} / \mathrm{g}), \mathrm{pH} 6$ for $\mathrm{Cd}(\mathrm{II})(70.0 \mu \mathrm{mol} / \mathrm{g})$ and $\mathrm{Cu}(\mathrm{II})$ $(86.0 \mu \mathrm{mol} / \mathrm{g})$, and $\mathrm{pH} 7$ for $\mathrm{Zn}$ (II) $(81.0 \mu \mathrm{mol} / \mathrm{g})$. Amarasinghe and Williams [90] reported the sequestration of $\mathrm{Cu}$ using black tea waste in a $\mathrm{pH}$ range of 5-6, for a removal efficiency and maximum adsorption capacity of $77 \%$ and $48 \mathrm{mg} / \mathrm{g}$. The adsorption kinetics showed 
a rapid initial adsorption rate followed by a slower rate (15-20 min contact time), fitting the Langmuir and pseudo-second order kinetic models. In the same year, Š́ciban et al. [73] reported high adsorption efficiency for copper ions $(0.085 \mathrm{mmol} / \mathrm{g})$ by employing soybean straw, with low values for cadmium and nickel $(0.018$ and $0.007 \mathrm{mmol} / \mathrm{g}$, respectively). The authors found that copper adsorption increased to over $80 \%$ when the adsorbent material was chemically modified with $1 \% \mathrm{NaOH}$. Other agricultural byproducts (raw wheat straw and corn stalks) were evaluated for the adsorption of these heavy metals, obtaining higher $\mathrm{q}_{\mathrm{m}}$ values for cadmium $(0.089 \mathrm{mmol} / \mathrm{g})$ and nickel $(0.051 \mathrm{mmol} / \mathrm{g})$ using raw wheat straw [73].

The adsorption of chromium and lead from synthetic water by applying mixed tea waste obtained from a coffee shop showed a maximum $\mathrm{Cr}(\mathrm{VI})$ removal of approximately $97 \%$ after 180 min of contact time at $\mathrm{pH} 2$ [93]. This synthetic water consisted of tap water with trace concentrations of suspended organic and inorganic solids added to resemble municipal wastewater. Sulfonate-treated tea waste was an effective adsorbent for $\mathrm{Cr}(\mathrm{VI})$, exhibiting a removal efficiency of $96 \%$ and reaching equilibrium in the first $30 \mathrm{~min}$ [91]. Arris et al. [40] identified the optimal conditions for calcined cereal byproducts to achieve maximum chromium removal efficiency $(90.3 \%)$ at $\mathrm{pH}$ values ranging from 6 to 8 and a high initial metal concentration $(132 \mathrm{mg} / \mathrm{L})$. In a similar vein, Amer et al. [16] studied the optimal conditions for the retention of lead employing rice straw, concluding that when increasing the $\mathrm{pH}$ from 3.5 to 6 the removal of the metal exceeded $90 \%$. Date palm leaves, $\mathrm{SCB}$, and black tea were effective herbage adsorbents for capturing $\mathrm{Pb}$ (II) in aqueous solutions, with the former retaining more than $98 \%$ of the metal at a $\mathrm{pH}$ of $5.5-6.0[41,86]$ and the black tea showing a $94 \%$ removal and $\mathrm{q}_{\mathrm{m}}$ of $65 \mathrm{mg} / \mathrm{g}$ [90].

\subsubsection{Industrial Contaminants}

Barley straw has been chemically and magnetically modified for the removal of four water-soluble dyes: bismarck brown $Y$, crystal violet, safranin $\mathrm{O}$, and MB. The biomaterial modified with citric acid and $\mathrm{NaOH}$ presented the highest $\mathrm{q}_{\mathrm{m}}$ for bismarck brown $\mathrm{Y}$ $(524.3 \mathrm{mg} / \mathrm{g})$, followed by crystal violet $(473.2 \mathrm{mg} / \mathrm{g})$ and MB $(498.1 \mathrm{mg} / \mathrm{g})$, whereas its magnetic version attained the maximal adsorption for safranin $\mathrm{O}(460.7 \mathrm{mg} / \mathrm{g})$. In contrast, the native and magnetic barley straw exhibited $\mathrm{q}_{\mathrm{m}}$ values below 124.3 and $137.6 \mathrm{mg} / \mathrm{g}$, respectively [69]. Ansari et al. [70] reported the removal of MB using cauliflower leaves in a synthetic aqueous solution. The adsorption capacity of $149.22 \mathrm{mg} / \mathrm{g}$ fit the Freundlich model well and removed $\sim 88 \%$ of the dye, increasing the adsorbent concentration to $0.1 \mathrm{~g}$. Furthermore, Gupta et al. [84] found an alternative way to capture MB and malachite green using potato waste powder; potato leaves showed higher efficiency ( 87 and $75 \%$, respectively) than potato stems ( 82 and $67 \%$, respectively) for both dyes. Both adsorbents presented a porous, uneven, and rough surface structure, although the potato leaves evidenced a higher fixed carbon percentage $(2.15 \%$ vs. $1.725 \%)$, which may explain its higher removing capacity. In addition to the dye removal efficiencies and adsorption capacities (Table 5), the equilibrium data fit the Langmuir, Freundlich, and the pseudosecond order kinetics models for the different adsorbents described.

\subsubsection{Nutrients and Pharmaceuticals}

To resolve the imbalance caused by excess nutrients in water sources, Ismail [107] explored date palm wastes as an effective adsorbent for phosphate elimination. The removal percentages obtained at the initial $\mathrm{PO}_{4}{ }^{3-}$ concentration of $50 \mathrm{mg}$ were $87 \%$ for granular date stones and $85 \%$ for palm surface fibers. Regarding removal of pharmaceuticals, Liu et al. [85] developed a sustainable method to adsorb clofibric acid and carbamazepine from aqueous solutions by employing rice straw at different $\mathrm{pH}$ conditions and biomaterial concentrations. The adsorption of both drugs depended on the adsorbent dosage and the $\mathrm{pH}$. In the case of clofibric acid, 30 and $60 \mathrm{~g} / \mathrm{L}$ of straw at $\mathrm{pH} 3.1$ yielded the highest removal percentages ( 42.5 and $75.3 \%$, respectively). The adsorption isotherms confirmed 
that the bioadsorbents had a heterogeneous surface structure, as both pharmaceuticals better fit the Freundlich isotherm model (Table 5).

\section{Challenges and Future Perspectives}

Agricultural waste has been demonstrated to be one of the most interesting materials for water remediation due to its ability to adsorb heavy metals, dyes, nutrients, pharmaceuticals, and other contaminants. Nevertheless, several variables that represent a challenging perspective in the near future need to be considered during the recovery process from water sources. One of these is the lifetime and final disposal of the biomaterial, which could negatively impact both the environment and the cost of the procedures. The most common disposal method, due to its low cost and reliability, is chemical neutralization of spent bioadsorbents, which are later placed in a landfill. Despite being a simple mechanism, this entails the possibility of secondary contamination of the soil, groundwater, surface water, and air, especially if the landfill lacks appropriate leachate and gas collection systems [108]. Another popular strategy to discard used biomaterials is incineration, which results in high reduction of the biomass at the cost of possible secondary pollution through the emission of gases and fly ash that may contain trace amounts of the adsorbed contaminants [109]. However, there are other heat treatments used to extend the lifecycle of adsorbents or regenerate biochars, such as hydrothermal modification, gasification, and pyrolysis; regardless of the benefits of recycling byproducts, high costs represent a considerable limitation for the industry [109].

Microbial degradation has been studied as a recovery method for exhausted bioadsorbents. Unfortunately, it has several disadvantages that make it an unsuitable alternative at industrial scales, for example, its long degradation time, high sediment production, and the high sensitivity of the processes [110]. On the other hand, the chemical extraction of contaminants with sulfuric acid or EDTA, among others, displays satisfactory results in recovering and recycling both heavy metals and extractants [111,112]. A fairly new strategy with promising outcomes has recently been studied, although it requires further research; this is the biosynthesis of nanomaterials using bioadsorbents as raw material [113].

Other challenges related to the use of bioadsorbents include the wide range of contaminants and the hydrological dynamics existing in different water sources. In this review, only four contaminant categories have been taken into consideration; however, it is necessary to explore other bioadsorbents that have been used to remove personal care and other lifestyle products such as galaxolide, tonalide [114-116], saccharin, sucralose, and caffeine [117-120]. Other known groups that form the growing list of emerging contaminants are chemical synthesizers and intermediates, corrosion inhibitors, flame retardants, plasticizers, per- and polyfluorinated compounds, biocides, hormones, resistance genes, etc. [121-125]. These emerging contaminants make more crucial the development of future research on the adsorption of these contaminants through the implementation of agricultural residues. Finally, the behavior of bioadsorbents in the treatment of other water sources, including groundwater, surface water, marine water, and different environmental matrices such as landfill leachates and industrial gas emissions, is another matter requiring further investigation. The current methodologies and protocols for the manufacturing of biowastes should be improved, with the aim of enhancing the adsorption process and favoring the implementation of bioadsorbents by further reducing costs.

\section{Conclusions}

In this review, the most notable outcomes were obtained for fruit-based bioadsorbents, with removal efficiencies of $100 \%$ or higher (predicted efficiency using response surface methodology) for adsorption of fluoride ions and congo red dye, respectively. Regarding adsorbents derived from seeds, AC from Acacia erioloba seed pods and Argania Spinosa tree nutshells $-\mathrm{TiO}_{2}$ achieved the removal of $100 \%$ of $\mathrm{MB}$ and diclofenac. Forage and herbage adsorbents presented lower removal efficiencies; however, tea waste and SCB were suitable alternatives for the adsorption of $\mathrm{Zn}, \mathrm{Mn}$, and $\mathrm{MB}$, with efficiencies around $99 \%$. In most 
of these treatments, the effects of the initial adsorbate concentration, adsorbent dosage, contact time, and $\mathrm{pH}$ were critical for evaluation of biomaterial efficiency, in most cases involving a change in the ionic charges that govern the interaction between contaminants and adsorbents. However, it is necessary to continue studying these conditions in order to optimize the use and yield of bioadsorbents that could help solve the most challenging environmental problems involved in water pollution. Another aspect to consider is the use of recycled $\mathrm{AC}$ activators to reduce both environmental impacts and manufacturing costs. Moreover, in some cases the application of chemical activators is not required (e.g., in moringa biochar), avoiding the cost of chemical pretreatment.

In conclusion, this review highlights the wide availability of agricultural materials, reporting more than 60 bioadsorbents and the conditions under which they can most effectively adsorb heavy metals, dyes, pharmaceuticals, nutrients, and other contaminants that alter water sources. Further multidisciplinary studies are needed in order to apply the reviewed bioadsorbents on industrial scales while abiding by the relevant environmental policies of each sector. Lastly, it is imperative to enforce the regulations concerning industrial discharge, water safety, and waste control in order to reduce environmental impacts of anthropogenic origin.

Author Contributions: Writing—original draft preparation, J.A.-R., M.E.U.-L., B.E.R.-G. and S.X.L.-V.; writing - review and editing, I.E.L.-C. and D.L.C.-C.; supervision, D.L.C.-C. All authors have read and agreed to the published version of the manuscript.

Funding: This research received no external funding.

Institutional Review Board Statement: Not applicable.

Informed Consent Statement: Not applicable.

Acknowledgments: This work was supported by Consejo Nacional de Ciencia y Tecnología of Mexico (Scholarship No. 1103630).

Conflicts of Interest: The authors declare no conflict of interest.

\section{References}

1. Bhatnagar, A.; Sillanpää, M.; Witek-Krowiak, A. Agricultural waste peels as versatile biomass for water purification-A review. Chem. Eng. J. 2015, 270, 244-271. [CrossRef]

2. Food and Agriculture Organization of the United Nations. Water Pollution from Agriculture: A Global Review. Executive Summary. Available online: https://www.fao.org/3/i7754e/i7754e.pdf (accessed on 21 August 2021).

3. Bhattacharjee, C.; Dutta, S.; Saxena, V.K. A review on biosorptive removal of dyes and heavy metals from wastewater using watermelon rind as biosorbent. Environ. Adv. 2020, 2, 100007. [CrossRef]

4. Karim, M.A.H.; Aziz, K.H.H.; Omer, K.M.; Salih, Y.M.; Mustafa, F.; Rahman, K.O.; Mohammad, Y. Degradation of aqueous organic dyes pollutants by heterogeneous photo-assisted Fenton-like process using natural mineral activator: Parameter optimization and degradation kinetics. IOP Conf. Ser. Earth Environ. Sci. 2021, 958, 012011. [CrossRef]

5. Abdulla, S.M.; Jamil, D.M.; Aziz, K.H.H. Investigation in heavy metal contents of drinking water and fish from Darbandikhan and Dokan Lakes in Sulaimaniyah Province-Iraqi Kurdistan Region. IOP Conf. Ser. Earth Environ. Sci. 2020, 612, 012023. [CrossRef]

6. Pesqueria, J.F.J.R.; Pereira, M.F.R.; Silva, A.M.T. Environmental impact assessment of advanced urban wastewater treatment technologies for the removal of priority substances and contaminants of emerging concern: A review. J. Clean. Prod. 2020, 261, 121078. [CrossRef]

7. Ramírez-Malule, H.; Quiñones-Murillo, D.H.; Manotas-Duque, D. Emerging contaminants as global environmental hazards. A bibliometric analysis. Emerg. Contam. 2020, 6, 179-193. [CrossRef]

8. Intisar, A.; Ramzan, A.; Sawaira, T.; Kareem, A.T.; Hussain, N.; Din, M.I.; Bilal, M.; Iqbal, H.M.N. Occurrence, toxic effects, and mitigation of pesticides as emerging environmental pollutants using robust nanomaterials-A review. Chemosphere 2022, 293, 133538. [CrossRef]

9. World Water Assessment Programme (UNESCO WWAP). The United Nations World Water Development Report 2015: Water for a Sustainable World. Available online: http://www.unesco.org/new/en/natural-sciences/environment/water/wwap/wwdr/ 2015-water-for-a-sustainable-world (accessed on 8 November 2021).

10. Bhatnagar, A.; Sillanpää, M. Utilization of agro-industrial and municipal waste materials as potential adsorbents for water treatment-A review. Chem. Eng. J. 2010, 157, 277-296. [CrossRef]

11. Sanchez-Silva, J.M.; González-Estrada, R.R.; Blancas-Benitez, F..; Fonseca-Cantabrana, N. Utilización de subproductos agroindustriales para la bioadsorción de metales pesados. TIP 2020, 23, 1-18. [CrossRef] 
12. Saravanan, A.; Senthil Kumar, P.; Jeevanantham, S.; Karishma, S.; Tajsabreen, B.; Yaashikaa, P.; Reshma, B. Effective water/wastewater treatment methodologies for toxic pollutants removal: Processes and applications towards sustainable development. Chemosphere 2021, 280, 130595. [CrossRef]

13. Volesky, B. Biosorption and me. Water Res. 2007, 41, 4017-4029. [CrossRef] [PubMed]

14. De Gisi, S.; Lofrano, G.; Grassi, M.; Notarnicola, M. Characteristics and adsorption capacities of low-cost sorbents for wastewater treatment: A review. Sustain. Mater. Technol. 2016, 9, 10-40. [CrossRef]

15. Rudi, N.N.; Muhamad, M.S.; te Chuan, L.; Alipal, J.; Omar, S.; Hamidon, N.; Abdul Hamid, N.H.; Mohamed Sunar, N.; Ali, R.; Harun, H. Evolution of adsorption process for manganese removal in water via agricultural waste adsorbents. Heliyon 2020, 6 , e05049. [CrossRef] [PubMed]

16. Amer, H.; El-Gendy, A.; El-Haggar, S. Removal of lead (II) from aqueous solutions using rice straw. Water Sci. Technol. 2017, 76, 1011-1021. [CrossRef] [PubMed]

17. Shafiq, M.; Alazba, A.A.; Amin, M.T. Removal of Heavy Metals from Wastewater using Date Palm as a Biosorbent: A Comparative Review. Sains Malays. 2018, 47, 35-49. [CrossRef]

18. De Andrade, J.R.; Oliveira, M.F.; da Silva, M.G.C.; Vieira, M.G.A. Adsorption of Pharmaceuticals from Water and Wastewater Using Nonconventional Low-Cost Materials: A Review. Ind. Eng. Chem. Res. 2018, 57, 3103-3127. [CrossRef]

19. Salman, A.; Ibrahim, I.; Tarek, M.; Abbas, S. Biosorption of heavy metals: A review. J. Chem. Sci. Technol. $2014,3,74-102$.

20. Wang, J.; Guo, X. Adsorption isotherm models: Classification, physical meaning, application and solving method. Chemosphere 2020, 258, 127279. [CrossRef]

21. Kaur, S.; Rani, S.; Mahajan, R.K.; Asif, M.; Gupta, V.K. Synthesis and adsorption properties of mesoporous material for the removal of dye safranin: Kinetics, equilibrium, and thermodynamics. J. Ind. Eng. Chem. 2015, 22, 19-27. [CrossRef]

22. Piccin, J.S.; Dotto, G.L.; Pinto, A.A. Adsorption isotherms and thermochemical data of FD\&C red $n^{\circ} 40$ binding by chitosan. Braz. J. Chem. Eng. 2011, 28, 295-304. [CrossRef]

23. Ray, S.S.; Gusain, R.; Kumar, N. Adsorption equilibrium isotherms, kinetics and thermodynamics. In Carbon Nanomaterial-Based Adsorbents for Water Purification Fundamentals and Applications, 1st ed.; Ray, S.S., Gusain, R., Neeraj, K., Eds.; Elsevier: Amsterdam, The Netherlands, 2020; pp. 101-118. [CrossRef]

24. Largitte, L.; Pasquier, R. A review of the kinetics adsorption models and their application to the adsorption of lead by an activated carbon. Chem. Eng. Res. Des. 2016, 109, 495-504. [CrossRef]

25. Jones, A.N.; Bridgeman, J. A fluorescence-based assessment of the fate of organic matter in water treated using crude/purified Hibiscus seeds as coagulant in drinking water treatment. Sci. Total Environ. 2019, 646, 1-10. [CrossRef] [PubMed]

26. Ueda Yamaguchi, N.; Cusioli, L.F.; Quesada, H.B.; Camargo Ferreira, M.E.; Fagundes-Klen, M.R.; Salcedo Vieira, A.M.; Bergamasco, R. A review of Moringa oleifera seeds in water treatment: Trends and future challenges. Process. Saf. Environ. Prot. 2021, 147, 405-420. [CrossRef]

27. Jjagwe, J.; Olupot, P.W.; Menya, E.; Kalibbala, H.M. Synthesis and application of Granular activated carbon from biomass waste materials for water treatment: A review. J. Bioresour. Bioprod. 2021, 4, 292-322. [CrossRef]

28. Edathil, A.A.; Shittu, I.; Hisham Zain, J.; Banat, F.; Haija, M.A. Novel magnetic coffee waste nanocomposite as effective bioadsorbent for $\mathrm{Pb}$ (II) removal from aqueous solutions. J. Environ. Chem. Eng. 2018, 6, 2390-2400. [CrossRef]

29. Sciban, M.; Antov, M.G.; Klasnja, M. Extraction and partial purification of coagulation active components from common bean seed. Acta Period. Technol. 2006, 37, 37-43. [CrossRef]

30. Bodlund, I.; Pavankumar, A.R.; Chelliah, R.; Kasi, S.; Sankaran, K.; Rajarao, G.K. Coagulant proteins identified in mustard: A potential water treatment agent. Int. J. Environ. Sci. Technol. 2014, 11, 873-880. [CrossRef]

31. Foo, K.Y.; Hameed, B.H. Preparation and characterization of activated carbon from sunflower seed oil residue via microwave assisted $\mathrm{K}_{2} \mathrm{CO}_{3}$ activation. Bioresour. Technol. 2011, 102, 9794-9799. [CrossRef]

32. Jayasree, R.; Kumar, P.S.; Saravanan, A.; Hemavathy, R.V.; Yaashikaa, P.R.; Arthi, P.; Choi, K.C. Sequestration of toxic Pb(II) ions using ultrasonic modified agro waste: Adsorption mechanism and modelling study. Chemosphere 2021, 285, 131502. [CrossRef]

33. Aguayo-Villarreal, I.A.; Bonilla-Petriciolet, A.; Muñiz-Valencia, R. Preparation of activated carbons from pecan nutshell and their application in the antagonistic adsorption of heavy metal ions. J. Mol. Liq. 2017, 230, 686-695. [CrossRef]

34. Williams, P.T.; Reed, A.R. Development of activated carbon pore structure via physical and chemical activation of biomass fibre waste. Biomass Bioenergy 2006, 30, 144-152. [CrossRef]

35. Marsh, H.; Rodríguez-Reinoso, F. Activation Processes (Chemical). In Activated Carbon, 1st ed.; Marsh, H., Rodríguez-Reinoso, F., Eds.; Elsevier Science Ltd.: Amsterdam, The Netherlands, 2006; pp. 322-365. [CrossRef]

36. Yi, H.; Nakabayashi, K.; Yoon, S.-H.; Miyawaki, J. Pressurized physical activation: A simple production method for activated carbon with a highly developed pore structure. Carbon 2021, 183, 735-742. [CrossRef]

37. Anirudhan, T.; Sreekumari, S. Adsorptive removal of heavy metal ions from industrial effluents using activated carbon derived from waste coconut buttons. J. Environ. Sci. 2011, 23, 1989-1998. [CrossRef]

38. Shin, J.; Kwak, J.; Lee, Y.G.; Kim, S.; Choi, M.; Bae, S.; Chon, K. Competitive adsorption of pharmaceuticals in lake water and wastewater effluent by pristine and $\mathrm{NaOH}$-activated biochars from spent coffee wastes: Contribution of hydrophobic and $\pi-\pi$ interactions. Environ. Pollut. 2021, 270, 116244. [CrossRef]

39. Abbaszadeh, S.; Alwi, S.R.W.; Webb, C.; Ghasemi, N.; Muhamad, I.I. Treatment of lead-contaminated water using activated carbon adsorbent from locally available papaya peel biowaste. J. Clean. Prod. 2016, 118, 210-222. [CrossRef] 
40. Arris, S.; Bencheikh Lehocine, M.; Meniai, A.H. Sorption study of chromium sorption from wastewater using cereal by-products. Int. J. Hydrogen Energy 2014, 41, 10299-10310. [CrossRef]

41. Soliman, A.M.; Elwy, H.M.; Thiemann, T.; Majedi, Y.; Labata, F.T.; Al-Rawashdeh, N.A. Removal of Pb(II) ions from aqueous solutions by sulphuric acid-treated palm tree leaves. J. Taiwan Inst. Chem. Eng. 2016, 58, 264-273. [CrossRef]

42. Garg, D.; Kumar, S.; Sharma, K.; Majumder, C.B. Application of waste peanut shells to form activated carbon and its utilization for the removal of Acid Yellow 36 from wastewater. Groundw. Sustain. Dev. 2019, 8, 512-519. [CrossRef]

43. Rahman, A.; Hango, H.J.; Daniel, L.S.; Uahengo, V.; Jaime, S.J.; Bhaskaruni, S.V.H.S.; Jonnalagadda, S.B. Chemical preparation of activated carbon from Acacia erioloba seed pods using $\mathrm{H}_{2} \mathrm{SO}_{4}$ as impregnating agent for water treatment: An environmentally benevolent approach. J. Clean. Prod. 2019, 237, 117689. [CrossRef]

44. Jung, K.W.; Choi, B.H.; Hwang, M.J.; Jeong, T.U.; Ahn, K.H. Fabrication of granular activated carbons derived from spent coffee grounds by entrapment in calcium alginate beads for adsorption of acid orange 7 and methylene blue. Bioresour. Technol. 2016, 219, 185-195. [CrossRef]

45. Pereira, R.G.; Veloso, C.M.; da Silva, N.M.; de Sousa, L.F.; Bonomo, R.C.F.; de Souza, A.O.; da Guarda Souza, M.O.; da Costa Ilhéu Fontan, R. Preparation of activated carbons from cocoa shells and siriguela seeds using $\mathrm{H}_{3} \mathrm{PO}_{4}$ and $\mathrm{ZnCl}$ as activating agents for BSA and $\alpha$-lactalbumin adsorption. Fuel Process. Technol. 2014, 126, 476-486. [CrossRef]

46. Namasivayam, C.; Kavitha, D. Removal of Congo red from water by adsorption onto activated carbon prepared from coir pith, an agricultural solid waste. Dye. Pigm. 2002, 54, 47-58. [CrossRef]

47. Namasivayam, C.; Radhika, R.; Suba, S. Uptake of dyes by a promising locally available agricultural solid waste: Coir pith. J. Waste Manag. 2001, 21, 381-387. [CrossRef]

48. Mahamad, M.N.; Zaini, M.A.A.; Zakaria, Z.A. Preparation and characterization of activated carbon from pineapple waste biomass for dye removal. Int. Biodeterior. Biodegrad. 2015, 102, 274-280. [CrossRef]

49. Yadav, D.; Kapur, M.; Kumar, P.; Mondal, M.K. Adsorptive removal of phosphate from aqueous solution using rice husk and fruit juice residue. Process. Saf. Environ. Prot. 2015, 94, 402-409. [CrossRef]

50. Isiuku, B.O.; Enyoh, C.E.; Duru, C.E.; Ibe, F.C. Phosphate ions removal from aqueous phase by batch adsorption on activated (activation before carbonization) biochar derived from rubber pod husk. Curr. Res. Green Sustain. Chem. 2021, 4, 100136. [CrossRef]

51. De Luna, M.D.G.; Murniati; Budianta, W.; Rivera, K.K.; Arazo, R.O. Removal of sodium diclofenac from aqueous solution by adsorbents derived from cocoa pod husks. J. Environ. Chem. Eng. 2017, 5, 1465-1474. [CrossRef]

52. El Mouchtari, E.M.; Daou, C.; Rafqah, S.; Najjar, F.; Anane, H.; Piram, A.; Hamade, A.; Briche, S.; Wong-Wah-Chung, P. TiO 2 and activated carbon of Argania Spinosa tree nutshells composites for the adsorption photocatalysis removal of pharmaceuticals from aqueous solution. J. Photochem. Photobiol. A Chem. 2020, 388, 112183. [CrossRef]

53. Chakraborty, P.; Banerjee, S.; Kumar, S.; Sadhukhan, S.; Halder, G. Elucidation of ibuprofen uptake capability of raw and steam activated biochar of Aegle marmelos shell: Isotherm, kinetics, thermodynamics and cost estimation. Process. Saf. Environ. Prot. 2018, 118, 10-23. [CrossRef]

54. Cabrita, I.; Ruiz, B.; Mestre, A.; Fonseca, I.; Carvalho, A.; Ania, C. Removal of an analgesic using activated carbons prepared from urban and industrial residues. Chem. Eng. J. 2010, 163, 249-255. [CrossRef]

55. Mora Alvarez, N.M.; Pastrana, J.M.; Lagos, Y.; Lozada, J.J. Evaluation of mercury $\left(\mathrm{Hg}^{2+}\right)$ adsorption capacity using exhausted coffee waste. Sustain. Chem. Pharm. 2018, 10, 60-70. [CrossRef]

56. Araújo, C.; Melo, E.; Alves, V.; Coelho, N.M.M. Moringa oleifera Lam. Seeds as a Natural Solid Adsorbent for Removal of AgI in Aqueous Solutions. J. Braz. Chem. Soc. 2010, 21, 1727-1732. [CrossRef]

57. Çelekli, A.; Al-Nuaimi, A.I.; Bozkurt, H. Adsorption kinetic and isotherms of Reactive Red 120 on Moringa oleifera seed as an eco-friendly process. J. Mol. Struct. 2019, 1195, 168-178. [CrossRef]

58. Obeng, G.Y.; Amoah, D.Y.; Opoku, R.; Sekyere, C.K.; Adjei, E.A.; Mensah, E. Coconut wastes as bioresource for sustainable energy: Quantifying wastes, calorific values and emissions in Ghana. Energies 2020, 13, 2178. [CrossRef]

59. Parab, H.; Joshi, S.; Shenoy, N.; Lali, A.; Sarma, U.S.; Sudersanan, M. Determination of kinetic and equilibrium parameters of the batch adsorption of $\mathrm{Co}(\mathrm{II}), \mathrm{Cr}(\mathrm{III})$ and $\mathrm{Ni}(\mathrm{II})$ onto coir pith. Process. Biochem. 2006, 41, 609-615. [CrossRef]

60. Memon, J.R.; Memon, S.Q.; Bhanger, M.I.; Memon, G.Z.; El-Turki, A.; Allen, G.C. Characterization of banana peel by scanning electron microscopy and FT-IR spectroscopy and its use for cadmium removal. Colloids Surf. B Biointerfaces 2008, 66, 260-265. [CrossRef]

61. Memon, J.R.; Memon, S.Q.; Bhanger, M.I.; El-Turki, A.; Hallam, K.R.; Allen, G.C. Banana peel: A green and economical sorbent for the selective removal of $\mathrm{Cr}(\mathrm{VI})$ from industrial wastewater. Colloids Surf. B Biointerfaces 2009, 70, 232-237. [CrossRef]

62. Liu, C.; Ngo, H.H.; Guo, W. Watermelon Rind: Agro-waste or Superior Biosorbent? Appl. Biochem. Biotechnol. 2012, 167, 1699-1715. [CrossRef]

63. Liu, C.; Ngo, H.H.; Guo, W.; Tung, K.L. Optimal conditions for preparation of banana peels, sugarcane bagasse and watermelon rind in removing copper from water. Bioresour. Technol. 2012, 119, 349-354. [CrossRef]

64. Banerjee, K.; Ramesh, S.T.; Gandhimathi, R.; Nidheesh, P.V.; Bharathi, K.S. A novel agricultural waste adsorbent, watermelon shell for the removal of copper from aqueous solutions. Iran. J. Energy Environ. 2012, 3, 143-156. [CrossRef]

65. Gupta, H.; Gogate, P.R. Intensified removal of copper from waste water using activated watermelon based biosorbent in the presence of ultrasound. Ultrason. Sonochem. 2016, 30, 113-122. [CrossRef] [PubMed]

66. Reddy, N.A.; Lakshmipathy, R.; Sarada, N.C. Application of Citrullus lanatus rind as biosorbent for removal of trivalent chromium from aqueous solution. Alex. Eng. J. 2014, 53, 969-975. [CrossRef] 
67. Annadurai, G.; Juang, R.S.; Lee, D.J. Use of cellulose-based wastes for adsorption of dyes from aqueous solutions. J. Hazard. Mater. 2002, 92, 263-274. [CrossRef]

68. Mondal, N.K.; Roy, A. Potentiality of a fruit peel (banana peel) toward abatement of fluoride from synthetic and underground water samples collected from fluoride affected villages of Birbhum district. Appl. Water Sci. 2018, 8, 90. [CrossRef]

69. Baldikova, E.; Politi, D.; Maderova, Z.; Pospiskova, K.; Sidiras, D.; Safarikova, M.; Safarik, I. Utilization of magnetically responsive cereal by-product for organic dye removal. J. Sci. Food Agric. 2015, 96, 2204-2214. [CrossRef] [PubMed]

70. Ansari, S.A.; Khan, F.; Ahmad, A. Cauliflower Leave, an Agricultural Waste Biomass Adsorbent, and Its Application for the Removal of MB Dye from Aqueous Solution: Equilibrium, Kinetics, and Thermodynamic Studies. Int. J. Anal. Chem. 2016, 1-10. [CrossRef]

71. Paredes-Laverde, M.; Silva-Agredo, J.; Torres-Palma, R.A. Removal of norfloxacin in deionized, municipal water and urine using rice (Oryza sativa) and coffee (Coffea arabica) husk wastes as natural adsorbents. J. Environ. Manag. 2018, 213, 98-108. [CrossRef]

72. Etim, U.; Umoren, S.; Eduok, U. Coconut coir dust as a low cost adsorbent for the removal of cationic dye from aqueous solution. J. Saudi Chem. Soc. 2016, 20, S67-S76. [CrossRef]

73. Šćlban, M.; Klašnja, M.; ŠKrbić, B. Adsorption of copper ions from water by modified agricultural by-products. Desalination 2008, 229, 170-180. [CrossRef]

74. Hameed, B.H.; Hakimi, H. Utilization of durian (Durio zibethinus Murray) peel as low cost sorbent for the removal of acid dye from aqueous solutions. Biochem. Eng. J. 2008, 39, 338-343. [CrossRef]

75. Saeed, A.; Sharif, M.; Iqbal, M. Application potential of grapefruit peel as dye sorbent: Kinetics, equilibrium and mechanism of crystal violet adsorption. J. Hazard. Mater. 2010, 179, 564-572. [CrossRef] [PubMed]

76. Hameed, B.H. Removal of cationic dye from aqueous solution using jackfruit peel as non-conventional low-cost adsorbent. J. Hazard. Mater. 2009, 162, 344-350. [CrossRef]

77. Al-Qahtani, K.M. Water purification using different waste fruit cortexes for the removal of heavy metals. J. Taibah Univ. Sci. 2016, 10, 700-770. [CrossRef]

78. Iqbal, M.; Saeed, A.; Zafar, S.I. FTIR spectrophotometry, kinetics and adsorption isotherms modeling, ion exchange, and EDX analysis for understanding the mechanism of $\mathrm{Cd}^{2+}$ and $\mathrm{Pb}^{2+}$ removal by mango peel waste. J. Hazard. Mater. 2009, 164, 161-171. [CrossRef]

79. Phanthuwongpakdee, J.; Babel, S.; Laohhasurayotin, K.; Sattayaporn, S.; Kaneko, T. Anthocyanin based agricultural wastes as bio-adsorbents for scavenging radioactive iodide from aqueous environment. J. Environ. Chem. Eng. 2020, 8, 104147. [CrossRef]

80. Namasivayam, C.; Muniasamy, N.; Gayatri, K.; Rani, M.; Ranganathan, K. Removal of dyes from aqueous solutions by cellulosic waste orange peel. Bioresour. Technol. 1996, 57, 37-43. [CrossRef]

81. Arami, M.; Limaee, N.Y.; Mahmoodi, N.M.; Tabrizi, N.S. Removal of dyes from colored textile wastewater by orange peel adsorbent: Equilibrium and kinetic studies. J. Colloid Interface. Sci. 2005, 288, 371-376. [CrossRef] [PubMed]

82. Aryee, A.A.; Dovi, E.; Shi, X.; Han, R.; Li, Z.; Qu, L. Zirconium and iminodiacetic acid modified magnetic peanut husk as a novel adsorbent for the sequestration of phosphates from solution: Characterization, equilibrium and kinetic study. Colloids Surf. A Physicochem. Eng. Asp. 2021, 615, 126260. [CrossRef]

83. Argun, M.E.; Güclü, D.; Karatas, M. Adsorption of Reactive Blue 114 dye by using a new adsorbent: Pomelo peel. J. Ind. Eng. Chem. 2014, 20, 1079-1084. [CrossRef]

84. Gupta, N.; Kushwaha, A.K.; Chattopadhyaya, M. Application of potato (Solanum tuberosum) plant wastes for the removal of methylene blue and malachite green dye from aqueous solution. Arab. J. Chem. 2016, 9, S707-S716. [CrossRef]

85. Liu, Z.; Zhou, X.; Chen, X.; Dai, C.; Zhang, J.; Zhang, Y. Biosorption of clofibric acid and carbamazepine in aqueous solution by agricultural waste rice straw. J. Environ. Sci. 2013, 25, 2384-2395. [CrossRef]

86. Soliman, E.M.; Ahmed, S.A.; Fadl, A.A. Reactivity of sugar cane bagasse as a natural solid phase extractor for selective removal of Fe(III) and heavy-metal ions from natural water samples. Arab. J. Chem. 2011, 4, 63-70. [CrossRef]

87. Esfandiar, N.; Nasernejad, B.; Ebadi, T. Removal of Mn(II) from groundwater by sugarcane bagasse and activated carbon (a comparative study): Application of response surface methodology (RSM). J. Ind. Eng. Chem. 2014, 20, 3726-3736. [CrossRef]

88. Ahmed, S.; El-Roudi, A.M.; Salem, A.A. Removal of Mn(II) from Ground Water by Solid Wastes of Sugar Industry. J. Environ. Sci. Technol. 2015, 8, 338-351. [CrossRef]

89. Feizi, M.; Jalali, M. Removal of heavy metals from aqueous solutions using sunflower, potato, canola and walnut shell residues. $J$. Taiwan Inst. Chem. Eng. 2015, 54, 125-136. [CrossRef]

90. Amarasinghe, B.; Williams, R. Tea waste as a low cost adsorbent for the removal of $\mathrm{Cu}$ and $\mathrm{Pb}$ from wastewater. Chem. Eng. J. 2007, 132, 299-309. [CrossRef]

91. Ahsan, M.A.; Katla, S.K.; Islam, M.T.; Hernandez-Viezcas, J.A.; Martinez, L.M.; Díaz-Moreno, C.A.; Lopez, J.; Singamaneni, S.R.; Banuelos, J.; Gardea-Torresdey, J.; et al. Adsorptive removal of methylene blue, tetracycline and Cr(VI) from water using sulfonated tea waste. Environ. Technol. Innov. 2018, 11, 23-40. [CrossRef]

92. Badrealam, S.; Darrell, V.C.; Dollah, Z.; Mohamed-Latiff, M.F.P.; Handan, R. Adsorption of manganese and zinc in synthetic wastewater by tea waste (TW) as a low cost adsorbent. J. Phys. Conf. Ser. 2019, 1349, 012061. [CrossRef]

93. Cherdchoo, W.; Nithettham, S.; Charoenpanich, J. Removal of $\mathrm{Cr}(\mathrm{VI})$ from synthetic wastewater by adsorption onto coffee ground and mixed waste tea. Chemosphere 2019, 221, 758-767. [CrossRef]

94. Solangi, N.H.; Kumar, J.; Mazari, S.A.; Ahmed, S.; Fatima, N.; Mujawar, N.M. Development of fruit waste derived bio-adsorbents for wastewater treatment: A review. J. Hazard. Mater. 2021, 416, 125848. [CrossRef] 
95. Sivaraj, R.; Namasivayam, C.; Kadirvelu, K. Orange peel as an adsorbent in the removal of acid violet 17 (acid dye) from aqueous solutions. Waste Manag. 2001, 21, 105-110. [CrossRef]

96. Hou, S.X. Adsorption properties of pomelo peels against methylene blue in dye wastewater. Adv. Mater. Res. 2013, 634, 178-181. [CrossRef]

97. Nasrollahzadeh, M.; Atarod, M.; Sajjadi, M.; Sajadi, S.M.; Issaabadi, Z. Plant-Mediated Green Synthesis of Nanostructures: Mechanisms, Characterization, and Applications. Interface Sci. Technol. 2019, 28, 199-322. [CrossRef]

98. Bardestani, R.; Patience, G.S.; Kaliaguine, S. Experimental methods in chemical engineering: Specific surface area and pore size distribution measurements-BET, BJH, and DFT. Can. J. Chem. Eng. 2019, 97, 2781-2791. [CrossRef]

99. Yan, Y. Tribology and tribo-corrosion testing and analysis of metallic biomaterials. In Metals for Biomedical Devices: Woodhead Publishing Series in Biomaterials, 1st ed.; Niinomi, M., Ed.; Woodhead Publishing Ltd.: Sawston, UK, 2010; pp. 178-201. [CrossRef]

100. Ahsan, M.A.; Islam, M.T.; Imam, M.A.; Hyder, A.G.; Jabbari, V.; Dominguez, N.; Noveron, J.C. Biosorption of bisphenol A and sulfamethoxazole from water using sulfonated coffee waste: Isotherm, kinetic and thermodynamic studies. J. Environ. Chem. Eng. 2018, 6, 6602-6611. [CrossRef]

101. Chiang, C.H.; Chen, J.; Lin, J.H. Preparation of pore-size tunable activated carbon derived from waste coffee grounds for high adsorption capacities of organic dyes. J. Environ. Chem. Eng. 2020, 8, 103929. [CrossRef]

102. Wang, J.; Chen, C. Biosorbents for heavy metals removal and their future. Biotechnol. Adv. 2009, 27, 195-226. [CrossRef]

103. Ben-Ali, S.; Jaouali, I.; Souissi-Najar, S.; Ouederni, A. Characterization and adsorption capacity of raw pomegranate peel biosorbent for copper removal. J. Clean. Prod. 2017, 142, 3809-3821. [CrossRef]

104. Kumar, G.V.S.R.; Rao, K.S.; Yadav, A.; Kumar, M.L.; Sarathi, T.V.N. Biosorption of copper(II) and manganese(II) from waste water using low cost bio adsorbents. J. Indian Chem. Soc. 2018, 95, 1-8.

105. Baccar, R.; Sarrà, M.; Bouzid, J.; Feki, M.; Blánquez, P. Removal of pharmaceutical compounds by activated carbon prepared from agricultural by-product. Chem. Eng. J. 2012, 211, 310-317. [CrossRef]

106. Masoudian, N.; Rajabi, M.; Ghaedi, M. Titanium oxide nanoparticles loaded onto activated carbon prepared from bio-waste watermelon rind for the efficient ultrasonic-assisted adsorption of congo red and phenol red dyes from wastewaters. Polyhedron 2019, 173, 114105. [CrossRef]

107. Ismail, Z.Z. Kinetic study for phosphate removal from water by recycled date-palm wastes as agricultural by-products. Int. J. Environ. Stud. 2012, 69, 135-149. [CrossRef]

108. Ye, M.; Sun, M.; Chen, X.; Feng, Y.; Wan, J.; Liu, K.; Tian, D.; Liu, M.; Wu, J.; Schwab, A.P.; et al. Feasibility of sulfate-calcined eggshells for removing pathogenic bacteria and antibiotic resistance genes from landfill leachates. Waste Manag. 2017, 63, 275-283. [CrossRef]

109. Liu, Z.; Tran, K.-Q. A review on disposal and utilization of phytoremediation plants containing heavy metals. Ecotoxicol. Environ. Saf. 2021, 226, 112821. [CrossRef]

110. El Gamal, M.; Mousa, H.A.; El-Naas, M.H.; Zacharia, R.; Judd, S. Bio-regeneration of activated carbon: A comprehensive review. Sep. Purif. Technol. 2018, 197, 345-359. [CrossRef]

111. Reza, M.S.; Hasan, A.B.M.; Afroze, S.; Abu Bakar, M.; Taweekun, J.; Azad, A. Analysis on Preparation, Application, and Recycling of Activated Carbon to Aid in COVID-19 Protection. Int. J. Integr. Eng. 2020, 12, 233-244. [CrossRef]

112. Wu, F.; Zhao, T.; Yao, Y.; Jiang, T.; Wang, B.; Wang, M. Recycling supercapacitor activated carbons for adsorption of silver (I) and chromium (VI) ions from aqueous solutions. Chemosphere 2020, 238, 124638. [CrossRef]

113. Hassan, M.; Naidu, R.; Du, J.; Liu, Y.; Qi, F. Critical review of magnetic biosorbents: Their preparation, application, and regeneration for wastewater treatment. Sci. Total Environ. 2020, 702, 134893. [CrossRef]

114. Gao, Q.; Blum, K.M.; Gago-Ferrero, P.; Wiberg, K.; Ahrens, L.; Andersson, P.L. Impact of on-site wastewater infiltration systems on organic contaminants in groundwater and recipient waters. Sci. Total Environ. 2019, 651, 1670-1679. [CrossRef]

115. Moreau, M.; Hadfield, J.; Hughey, J.; Sanders, F.; Lapworth, D.J.; White, D.; Civil, W. A baseline assessment of emerging organic contaminants in New Zealand groundwater. Sci. Total Environ. 2019, 686, 425-439. [CrossRef] [PubMed]

116. Llamas-Dios, M.I.; Vadillo, I.; Jiménez-Gavilán, P.; Candela, L.; Corada-Fernández, C. Assessment of a wide array of contaminants of emerging concern in a Mediterranean water basin (Guadalhorce river, Spain): Motivations for an improvement of water management and pollutants surveillance. Sci. Total Environ. 2021, 788, 147822. [CrossRef] [PubMed]

117. Riva, F.; Castiglioni, S.; Fattore, E.; Manenti, A.; Davoli, E.; Zuccato, E. Monitoring emerging contaminants in the drinking water of Milan and assessment of the human risk. Int. J. Hyg. Environ. Health 2018, 221, 451-457. [CrossRef] [PubMed]

118. Yang, Y.Y.; Zhao, J.L.; Liu, Y.S.; Liu, W.R.; Zhang, Q.Q.; Yao, L.; Hu, L.X.; Zhang, J.N.; Jiang, Y.X.; Ying, G.G. Pharmaceuticals and personal care products (PPCPs) and artificial sweeteners (ASs) in surface and ground waters and their application as indication of wastewater contamination. Sci. Total Environ. 2018, 616, 816-823. [CrossRef] [PubMed]

119. Lee, H.-L.; Kim, K.Y.; Hamm, S.-Y.; Kim, M.S.; Kim, H.K.; Oh, J.-E. Occurrence and distribution of pharmaceutical and personal care products, artificial sweeteners, and pesticides in groundwater from an agricultural area in Korea. Sci. Total Environ. 2019, 659, 168-176. [CrossRef]

120. Sharma, B.J.; Bečanová, J.; Scheringer, M.; Sharma, A.; Bharat, G.K.; Whitehead, P.G.; Klánová, J.; Nizzetto, L. Health and ecological risk assessment of emerging contaminants (pharmaceuticals, personal care products, and artificial sweeteners) in surface and groundwater (drinking water) in the Ganges River Basin, India. Sci. Total Environ. 2019, 646, 1459-1467. [CrossRef] 
121. Alquwaizany, A.S.; Alfadul, S.M.; Khan, M.A.; Alabdulaaly, A.I. Occurrence of organic compounds in groundwater of Saudi Arabia. Environ. Monit. Assess. 2019, 191, 601. [CrossRef]

122. Hou, L.; Jiang, J.; Gan, Z.; Dai, Y.Y.; Yang, P.; Yan, Y.; Ding, S.; Su, S.; Bao, X. Spatial Distribution of Organophosphorus and Brominated Flame Retardants in Surface Water, Sediment, Groundwater, and Wild Fish in Chengdu, China. Arch. Environ. Contam. Toxicol. 2019, 77, 279-290. [CrossRef]

123. Close, M.E.; Humphries, B.; Northcott, G. Outcomes of the first combined national survey of pesticides and emerging organic contaminants (EOCs) in groundwater in New Zealand 2018. Sci. Total Environ. 2021, 754, 142005. [CrossRef]

124. Huang, H.; Liu, H.; Xiong, S.; Zeng, F.; Bu, J.; Zhang, B.; Liu, W.; Zhou, H.; Qi, S.; Xu, L.; et al. Rapid transport of organochlorine pesticides (OCPs) in multimedia environment from karst area. Sci. Total Environ. 2021, 775, 145698. [CrossRef]

125. Thompson, T.J.; Briggs, M.A.; Phillips, P.J.; Blazer, V.S.; Smalling, K.L.; Kolpin, D.W.; Wagner, T. Groundwater discharges as a source of phytoestrogens and other agriculturally derived contaminants to streams. Sci. Total Environ. 2021, 755, 142873. [CrossRef] 